\title{
Bifunctional Peptide-Based Opioid Agonist-Nociceptin Antagonist Ligands for Dual Treatment of Acute and Neuropathic Pain
}

\author{
Karel Guillemyn ${ }^{\dagger}$, Joanna Sarnowska ${ }^{\ddagger}$, Camille Lagard§, Jolanta Dyniewicz", Ewelina \\ Rojewska ${ }^{\ddagger}$, Joanna Mika ${ }^{\ddagger}$, Nga N. Chung ${ }^{\perp}$, Valérie Utard\#, Piotr Kosson", Andrzej W. \\ Lipkowski", Lucie Chevillard $\S$, Pol Arranz-Gibert ${ }^{\nabla}$, Meritxell Teixidó $\nabla$, Bruno Megarbane ${ }^{\S}$,

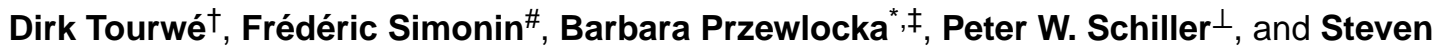 \\ Ballet ${ }^{*}$,
}

${ }^{\dagger}$ Research Group of Organic Chemistry, Departments of Chemistry and Bio-engineering Sciences, Vrije Universiteit Brussel, Pleinlaan 2, 1050 Brussels, Belgium ‡Department of Pain Pharmacology, Institute of Pharmacology, Polish Academy of Sciences, Smetna 12, PL 31-343 Kraków, Poland §Assistance Publique-Hôpitaux de Paris, Hôpital Lariboisière, Réanimation Médicale et Toxicologique, Inserm U1144, Université Paris Descartes UMR-S 1144, Université Paris Didero, UMR-S 1144, Paris, France "Neuropeptide Laboratory, Medical Research Centre, Polish Academy of Sciences, 5 Pawinskiego Street, PL 02-106 Warsaw, Poland ${ }^{\perp}$ Department of Chemical Biology and Peptide Research, Clinical Research Institute, 110 Avenue Des Pins Ouest, Montreal, Quebec H2W 1R7, Canada \#University of Strasbourg, CNRS, UMR7242, ESBS, 67412 Illkirch-Graffenstaden, France ${ }^{\nabla}$ Institute for Research in Biomedicine (IRB Barcelona), The Barcelona Institute of Science and Technology (BIST), Baldiri Reixac 10, 08028 Barcelona, Spain

\section{Abstract}

Herein, the opioid pharmacophore H-Dmt-p-Arg-Aba- $\beta$-Ala- $\mathrm{NH}_{2}$ (7) was linked to peptide ligands for the nociceptin receptor. Combination of 7 and NOP ligands (e.g., H-Arg-Tyr-Tyr-Arg-Ile-Lys$\mathrm{NH}_{2}$ ) led to binding affinities in the low nanomolar domain. In vitro, the hybrids behaved as agonists at the opioid receptors and antagonists at the nociceptin receptor. Intravenous

\footnotetext{
*Corresponding Authors, For S.B.: phone, 0032-26293292; fax, 0032-26293304; sballet@ vub.ac.be. "For B.P.: phone, 0048126623398; barbara.przewlocka@gmail.com.

ASSOCIATED CONTENT

Supporting Information

The Supporting Information is available free of charge on the ACS Publications website at DOI: 10.1021/acs.jmed-chem.5b01976.

Experimental in vivo and in vitro data, as well as NMR and HRMS details (PDF)

Molecular formula strings (CSV)

Author Contributions

K.G. performed synthesis and contributed to the paper writing. J.S. and E.R. prepared the mouse models of neuropathic pain and made all the experiments on neuropathic mice after it administration. J.M. and B.P. planned all experiments with neuropathic models, analyzed the results, and contributed to paper writing. L.C. and B.M. drafted the experimental protocol, and C.L. performed the experimental study of respiratory depression. C.L., L.C., and B.M. analyzed the data and contributed to the paper writing. V.U. performed radioligand binding and cAMP accumulation assays and analyzed the data. N.N.C. carried out the GPI and MVD assays. F.S. participated to the analysis of the data and to paper writing. D.T., P.W.S., and S.B. analyzed data, contributed to paper writing, and were in charge of the study. K.G. and J.S. authors contributed equally.

The authors declare no competing financial interest.
} 
administration of hybrid 13a (H-Dmt-D-Arg-Aba- $\beta$-Ala-Arg-Tyr-Tyr-Arg-Ile-Lys- $\mathrm{NH}_{2}$ ) to mice resulted in potent and long lasting antinociception in the tail-flick test, indicating that 13a was able to permeate the BBB. This was further supported by a cell-based BBB model. All hybrids alleviated allodynia and hyperalgesia in neuropathic pain models. Especially with respect to hyperalgesia, they showed to be more effective than the parent compounds. Hybrid 13a did not result in significant respiratory depression, in contrast to an equipotent analgesic dose of morphine. These hybrids hence represent a promising avenue toward analgesics for the dual treatment of acute and neuropathic pain.

\section{Graphical Abstract}

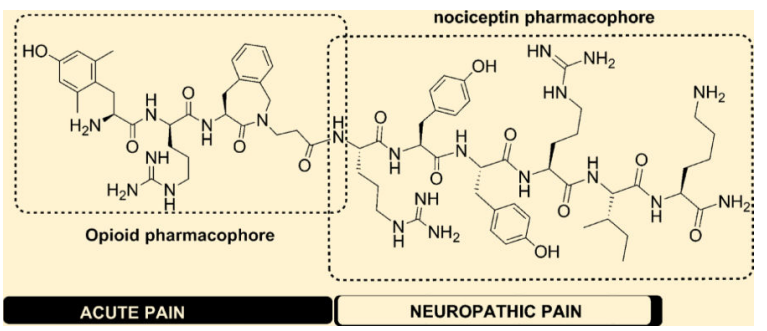

\section{INTRODUCTION}

The efficient treatment of pain remains of paramount importance to our society. Not only does it influence the individual's quality of life, it also significantly impacts healthcare systems around the world. Pain affects almost one in five adults across Europe (ca. 160 million people) and in the U.S., and one-third of all European households are affected by chronic pain. ${ }^{1}$ To overcome pain, potent opioids like morphine, oxycodone, buprenorphine (1), and fentanyl are widely prescribed. However, these drugs are not effective in all patients and may even be not well-tolerated as a consequence of deleterious effects such as constipation, ${ }^{2}$ nausea and vomiting, ${ }^{3}$ physical dependence,,${ }^{4,5}$ tolerance,${ }^{6}$ and respiratory depression. ${ }^{7}$ During the last 10 years, increasing prescriptions, availability, and misuse resulted in a rising number of fatalities due to respiratory depression in relation to unintentional opioid overdoses. ${ }^{8}$ Opioids represent about $8.6 \%$ of all drug-induced fatalities reported by the American Association of Poison Control Centers. ${ }^{9}$

To eliminate or reduce opioid-related side effects, other receptors involved in pain can be targeted. Examples of this strategy include the use of neurokinin-1 antagonists, ${ }^{10}$ neurotensin agonists, ${ }^{11,12}$ or nociceptin (ant)agonists ${ }^{13}$ in combination with opioids. The nociceptin receptor (NOP), previously called the opioid-receptor like-1 (ORL-1) receptor, is a G protein-coupled receptor that was discovered in 1994. ${ }^{14,15}$ The endogenous ligand of this receptor is the heptadecapeptide nociceptin/orphanin FQ (N/OFQ, H-Phe-Gly-Gly-PheThr-Gly-Ala-Arg-Lys-Ser-Ala-Arg-Lys-Leu-Ala-Asn-Gln-OH). Activation of the nociceptin receptor induces several biological responses including hypotension and immunodepression, and it strongly modulates nociceptive transmission and potentiates the effect of morphine in neuropathic pain. ${ }^{16,17}$ The nociceptin/orphanin FQ system seems to be involved in the modulation of acute nociceptive stimulation, as well as in chronic pain processes, for example, in inflammation ${ }^{18,19}$ and neuropathic pain. ${ }^{20-23}$ It is well established that N/OFQ 
may perform both pro- and antinociceptive actions, depending on the administration route ${ }^{24}$ or dosage, ${ }^{25}$ and both agonists and antagonists of NOP appear to be useful. ${ }^{16,24,26}$

NOP antagonists on their own do not demonstrate antinociceptive potency, neither in acute ${ }^{27}$ nor in neuropathic pain models, although they are reported to potentiate the antiallodynic effect of morphine under neuropathic conditions when coadministered iv, ${ }^{28}$ and to enhance DAMGO ([D-Ala, $\left.{ }^{2} \mathrm{NMePhe},{ }^{4} \mathrm{Gly}-\mathrm{ol}\right]$-enkephalin, MOP agonist) induced analgesia after microinjection to the ventrolateral periaqueductal gray, being the main output pathway involved in descending pain control. ${ }^{29}$ Natural N/OFQ administered intrathecally, but not supraspinally, induces naloxone insensitive antinociceptive actions in rhesus monkeys. ${ }^{30}$

NOP agonists in contrast may demonstrate powerful antinociceptive potency in acute pain but only in low doses $(0.001-1 \mathrm{nmol}$ it vs morphine $>1 \mathrm{nmol}$ it), as was demonstrated by Micheli and co-workers in rats. ${ }^{31}$ In the range of $0.001-1 \mathrm{nmol}$, a dose of $0.3 \mathrm{nmol}$ it administered NOP agonist [pF-Phe, $\left.{ }^{4} \mathrm{Aib},{ }^{7} \mathrm{Arg},{ }^{14} \mathrm{Lys}{ }^{15}\right] \mathrm{N} / \mathrm{OFQ}-\mathrm{NH}_{2}$ (UFP-112) afforded the highest antinociceptive effect. In addition, NOP agonists have not only been reported to be effective in acute pain but also not to lose their potency in neuropathic pain, as opioids do. ${ }^{32,33}$ Interestingly, morphine's effect in acute pain was significantly greater in naïve than in NOP(-/-) animals which suggests that the endogenous NOP system contributes to acute pain processing, at least in rats. Other authors report that this effect does not occur in mice models. ${ }^{34}$ NOP agonists proved to be especially potent in nonhuman primates, which suggests a promising outlook for human patients therapies. ${ }^{35}$ There is also evidence substantiating the use of NOP/MOP agonist hybrids in pain: intrathecal administration of a combination of inactive doses of UFP-112 and morphine attenuated hyperalgesia in rhesus monkeys. ${ }^{36}$ Consequently, targeting two distinct pathways to produce analgesia may potentiate the overall analgesic effect, while ameliorating side effects, for example by requiring lower doses.

Activation or blockage of distinct targets can be achieved by combination therapy (i.e., using drug cocktails) or by the use of designed multiple ligands (DMLs). ${ }^{37}$ The latter are single chemical entities able to bind two or more well-chosen receptor types. Although both strategies proved to be very useful, major advantages of DMLs consist of an early stage, thus less expensive optimization in the drug discovery process, and less complex pharmacokinetics. ${ }^{37}$ Several small molecules with nanomolar binding affinities at both the nociceptin and the opioid systems have been reported (Figure 1). ${ }^{28,38-44}$ Depending on their structural architectures, they behave as agonists, partial agonists, or antagonists on one or both of these systems. Several of these small molecule hybrids demonstrated interesting analgesic properties when tested in vivo. The high affinity, nonselective NOP/MOP partial agonist SR16435 (2) produced an antiallodynic response in the rat chronic constriction injury (CCI) model of neuropathic pain after intraperitoneal administration. ${ }^{45}$ In a thermal antinociception test, the development of analgesic tolerance was reduced compared with morphine. ${ }^{43}$ Co-administration of a NOP antagonist potentiated the antiallodynic effect of $\mathbf{2}$ and of morphine. This led the authors to suggest that NOP/MOP ligands with a dual profile of NOP antagonism and MOP agonism may be particularly useful for the treatment of chronic pain. ${ }^{45}$ 
Compound 3, a full NOP agonist and weak partial $(<20 \%)$ MOP agonist, did not have an effect in an acute pain model, but after subcutaneous administration to neuropathic sciatic nerve ligation (SNL) mice, it proved to possess an antiallodynic activity which could be suppressed by co-administration of a NOP, but not MOP, antagonist. ${ }^{43}$ However, compound 3 was less potent than morphine in the SNL model. This may implicate the need to find a proper balance between activation of MOP and NOP receptors in allodynia alleviation. ${ }^{28}$ Interestingly, cebranopadol 4, a highly potent agonist at MOP, DOP, KOP, and NOP, produced potent antinociception in rat models of acute and chronic pain and presented a clearly delayed development of tolerance. ${ }^{44,46}$

Also peptide and peptidomimetic bifunctional compounds have been reported. Kawano ${ }^{50}$ linked the opioid agonist dermorphin sequence to the Ac-RYYRIK- $\mathrm{NH}_{2}$ sequence that was shown to have high NOP affinity and to behave as an agonist, partial agonist, or antagonist depending on the assay. ${ }^{33,54,55}$ A synergistic and improved affinity for both the MOP and NOP was observed, leading to subnanomolar affinities when a long spacer -Gly-Gly-GlyLys(Gly-Gly-) was incorporated between the pharmacophores (5). In the mouse tail flick test, hybrid $\mathbf{5}$ showed an antinociceptive effect comparable to that of the isolated dermorphin sequence after it administration but less potent after icv administration. The antinociception was lower for the hybrid than for the coadministered opioid and nociceptin monomeric components despite the higher receptor affinities of the hybrid. No studies in neuropathic pain models were reported for hybrid $5 .{ }^{51}$ Becker ${ }^{52}$ screened a library of peptides, all incorporating $\beta$-turn inducing motifs for their binding at the opioid and nociceptin receptors and identified peptide III-BTD 6 with nanomolar binding affinities, and agonist properties at the opioid receptors and antagonist properties for NOP. ${ }^{52,53}$

On the basis of the potential of dual opioid-nociceptin ligands for the treatment of chronic and neuropathic pain, which remain an unmet medical need, we now report the design and synthesis of new DMLs. ${ }^{37}$ In contrast to the work of Kawano, the opioid part is directly connected to the nociceptin pharmacophore. ${ }^{50}$ The opioid agonist part consists of the earlier reported and optimized H-Dmt-D-Arg-Aba- $\beta$-Ala- $\mathrm{NH}_{2}$ tetrapeptide $7,{ }^{56}$ which is characterized by subnanomolar affinity and agonist activity for the opioid receptors. The nociceptin part is based on hexapeptides that were discovered by Dooley ${ }^{57}$ (i.e., Ac-Arg-TyrTyr-Arg-Ile-Lys- $\mathrm{NH}_{2}(\mathbf{8})$ and analogues). Substitution of the $\mathrm{N}$-terminal Ile-Lys dipeptide led to the Ac-Arg-Tyr-Tyr-Arg-Trp-Arg- $\mathrm{NH}_{2}$ sequence which has a $K_{\mathrm{i}}$ of $0.1 \mathrm{nM}$ for the human NOP and also behaves as a partial agonist in the $\left[{ }^{35} \mathrm{~S}\right] \mathrm{GTP} \gamma \mathrm{S}$ assay. ${ }^{54}$ The hexapeptides behave as partial agonists in cells expressing NOP, ${ }^{54,57}$ but antagonism has been observed in rat brain preparations and in acute and chronic pain models in mice and rats. ${ }^{33,55}$ Replacement of the $\mathrm{Tyr}^{3}$ residue in this hexapeptide with a para-fluorophenylalanine (pF-Phe) results in an even higher affinity $\left(K_{\mathrm{i}}=0.05 \mathrm{nM}\right){ }^{54}$ The latter product behaves as a partial agonist (70\% stimulation) similar to the parent compound. ${ }^{54}$ Introduction of a 2',6'-dimethyl---tyrosine (Dmt) residue at position 3 also gives a high affinity $\left(K_{\mathrm{i}}=0.04 \mathrm{nM}\right)$ partial agonist. ${ }^{54}$

The $N$-terminus of these four peptides was linked to the $C$-terminus of our opioid pharmacophore in order to obtain bifunctional peptides. These new bifunctional peptide ligands were evaluated in vitro for their affinity and activity on both the opioid and the 
nociceptin receptors, and additionally these compounds were tested in vivo for acute and neuropathic pain alleviation. One of the hybrids was examined for effects on respiratory depression.

\section{RESULTS AND DISCUSSION}

\section{Synthesis}

The targeted bifunctional peptides all contain a tetrahydro-4-amino-2-benzazepinone (Aba) subunit which serves as a conformationally constrained Phe analogue. Incorporation of this building block, which was previously developed by us, ${ }^{58,59}$ into several bioactive peptide sequences has successfully led to more stable and GPCR-subtype selective ligands and has provided highly potent opioid agonists. ${ }^{60-63}$ In the current work, its insertion into the desired opioid-nociceptin hybrids was realized in two ways (indicated as pathways A and B in Scheme 1).

Both strategies start with the synthesis of the resin-bound hexapeptides $\mathbf{1 0}$ by use of standard Fmoc-solid phase peptide synthesis (SPPS) on Rink amide AM resin. In pathway A, a segment condensation was performed between resin-bound 10 (with Xxx, $\operatorname{Tyr}(\mathrm{OtBu}$ ); Yyy, Ile; and Zzz, Lys(Boc)) and a preassembled protected tetrapeptide analogue Boc-Dmt-D$\operatorname{Arg}(\mathrm{Pbf})-\mathrm{Aba}-\beta-\mathrm{Ala}-\mathrm{OH}(\mathbf{1 1})$, which was prepared on 2-chlorotrityl resin, to obtain hybrid 12. The Aba- $\beta$-Ala component was formed directly on the solid support as previously reported. ${ }^{56}$ After full protecting group removal of $\mathbf{1 2}$ and simultaneous cleavage from the resin, the product was purified by means of preparative RP-HPLC to obtain the pure compound 13a. In route $\mathrm{B}$, dipeptide Fmoc-Aba- $\beta$-Ala-OH (14), was prepared by solution synthesis (Scheme 2 ) and coupled to the hexapeptides 10 to give 15. Fmoc-Aba- $\beta$-Ala-OH (14) was obtained, starting from phthaloyl protected phenylalanine 16 (Scheme 2), which was coupled to $\beta$-Ala-OEt. $\mathrm{HCl}$ using TBTU as coupling reagent and triethylamine as base. After crystallization of the resulting dipeptide 17, formation of the desired azepinone ring was achieved by use of an adapted literature procedure. ${ }^{64}$ Dipeptide 17 was mixed with trioxane, $\mathrm{AcOH}$, and $\mathrm{H}_{3} \mathrm{PO}_{4}$ in benzene at reflux in a Dean-Stark apparatus. $\mathrm{P}_{2} \mathrm{O}_{5}$ was added to avoid hydrolysis of the ester in the starting material due to the presence of traces of water. After refluxing for $4 \mathrm{~h}$, ring closure proved to be complete. Following workup and flash chromatography purification of the crude mixture, the ester in $\mathbf{1 8}$ was hydrolyzed with a $1 \mathrm{~N} \mathrm{HCl}$ in water/acetone $(1: 1)$ mixture at $90{ }^{\circ} \mathrm{C}$ for $16 \mathrm{~h}$ to isolate 19. The phthaloyl protecting group was then removed by hydrazinolysis. Subsequently, the free dipeptide was $\mathrm{N}$-protected with a Fmoc group and the pure and SPPS-compatible building block 14 was isolated after final purification with flash chromatography in $22 \%$ yield (over four steps). After coupling of dipeptide mimetic $\mathbf{1 4}$ onto resin-bound $\mathbf{1 0}$ (Scheme 1), further peptide elongation via SPPS, full deprotection, and cleavage from the resin, the final peptides of type 13 were obtained in high purity (>95\%) after preparative HPLC purification. The overall yield of pathway B was slightly higher and this pathway was easier to perform on larger scale $(0.2 \mathrm{mmol})$. Only the first sequence 13a was synthesized via both methods; the rest of the series (i.e., 13b-13d, Table 1) was synthesized by use of pathway B. To allow comparison with the parent nociceptin receptor ligands, compounds 8 (Ac-Arg-Tyr-Tyr-Arg- 
Ile-Lys- $\left.\mathrm{NH}_{2}\right)$ and $20\left(\mathrm{H}\right.$-Arg-Tyr-Tyr-Arg-Ile-Lys- $\left.\mathrm{NH}_{2}\right)$ were also prepared via SPPS and evaluated in vitro and in vivo.

\section{In Vitro Biological Evaluation}

In vitro binding and functional activity at the MOP, DOP, and KOP as well as at the nociceptin receptor were established for the parent $(\mathbf{7 , ~}, \mathbf{2}, \mathbf{2 0})$ and hybrid compounds $13 \mathrm{a}-\mathbf{d}$ (Table 2). In contrast to the parent structures, all hybrids maintained affinities within the moderate to low nanomolar range at both the opioid receptors and NOP. As expected, the parent structures possessed good binding only at the opioid or NOP receptors.

Hybrid 13a combines the opioid ligand 7 with the peptide Ac-RYYRIK-NH $\mathrm{N}_{2}$ 8. This fusion led to a decrease in nociceptin and opioid receptor binding compared to the parent compounds, which is in contrast to the synergistic effect reported for hybrid $5 .{ }^{51}$ In comparison to NOP, the effect was less pronounced at the opioid receptors. Changing the last two amino acids (Ile-Lys to Trp-Arg, see 13d) did not have a beneficial influence on affinity in contrast to the improvement observed in the parent compound (going from 1.5 to $0.6 \mathrm{nM}) .54,57$ Substitution of Tyr with para-fluoro phenylalanine gave a small decrease in opioid affinity for 13b, but the NOP binding improved almost 2-fold (47 to $27 \mathrm{nM}$ ). Introduction of a $2^{\prime}, 6^{\prime}$-dimethyltyrosine (Dmt) at this position (13c) improved DOP and KOP binding compared to 13b but with a slight drop in NOP affinity. With respect to nociceptin receptor binding, no significant differences were observed between the four investigated hybrids because the affinity varied maximally with a factor of 2 .

The in vitro opioid functional activity of the hybrids was verified by means of the guinea pig ileum (GPI) and mouse vas deferens (MVD) assays, representative of $\mu$ - and $\delta$-opioid receptor activity, respectively. In agreement with the affinity data of these compounds, low nanomolar activities were determined for all analogues, $\mathbf{1 3 b}$ being the most potent of the series. Some discrepancies between DOP receptor binding data and agonist potencies in the MVD assay were observed. For example, compound 13b showed quite low DOP binding affinity $\left(K_{\mathrm{i}}^{\delta}=194 \mathrm{nM}\right)$, but turned out to be a potent agonist in the MVD assay $\left(\mathrm{IC}_{50}=1.4\right.$ $\mathrm{nM})$. There is evidence to indicate that in the vas preparation a cooperative effect between MOP and DOP receptors may be produced by some compounds, ${ }^{65}$ and such cooperativity may be the cause for the unexpected high agonist potency of compound 13b. An alternative explanation would be that this compound may interact with another unknown receptor in the vas, as was also suggested to be the case with the NOP agonist/MOP partial agonist SR16476. ${ }^{66}$

The activity of nociceptin parent NOP ligands $\mathbf{8}$ and $\mathbf{2 0}$, as well as hybrid molecules 13a13d, was then assessed in the forskolin (FSK)-stimulated $3^{\prime}, 5^{\prime}$-cyclic adenosine monophosphate (cAMP) assay in HEK293 cells stably expressing the human NOP as described in the experimental section. As expected, nociceptin efficiently inhibited FSKstimulated cAMP production (Figure 2) with an $\mathrm{EC}_{50}$ of $0.23 \pm 0.02 \mathrm{nM}$. Compound $\mathbf{8}$ displayed partial agonist activity at NOP ( $70 \pm 1 \%$ of nociceptin maximum activity) with an $\mathrm{EC}_{50}$ of $29 \pm 1 \mathrm{nM}$, while $\mathbf{2 0}$ displayed neither agonist activity up to $10 \mu \mathrm{M}$ nor antagonist activity up to $20 \mu \mathrm{M}$ (Table 2). Hybrids 13a-13d did not display agonist activity at NOP up 
to $10 \mu \mathrm{M}$. Moreover, $20 \mu \mathrm{M}$ of each compound significantly shifted the dose-response curve of nociceptin to the right (Figure 2), indicating that they displayed antagonist properties at this receptor. We then determined $\mathrm{p} A_{2}$ values for each hybrid (Table 2). Our results show that 13a was the less potent NOP antagonist ( $\mathrm{p} A_{2}=5.39$ ), while the performed structural modifications led to improved antagonism for $\mathbf{1 3 b}-\mathbf{d}$, with $\mathrm{p} A_{2}$ values of $6.00,6.25$ and 6.01 , respectively.

\section{In Vitro BBB Permeation Assays}

To validate BBB permeation, a selected hybrid (13a) and its parent opioid (7) and NOP parent structures ( $\mathbf{8}$ and $\mathbf{2 0}$ ) were assayed in a PAMPA assay using porcine brain polar lipids as a model to study their passive diffusion transport through the blood-brain barrier (BBB $)^{67}$ at a concentration of $500 \mu \mathrm{M}$ in the donor compartment. Propranolol, a $\beta$-adrenergic receptor blocker with high brain penetration, was used as a positive control. Permeability $\left(P_{\mathrm{e}}\right)$ is considered excellent if values $>4.0 \times 10^{-6} \mathrm{~cm} / \mathrm{s}$, uncertain between $2.0 \times 10^{-6}$ and $4.0 \times$ $10^{-6} \mathrm{~cm} / \mathrm{s}$, and poor with values below $2.0 \times 10^{-6} \mathrm{~cm} / \mathrm{s} .{ }^{67}$ Thus, looking at the results depicted in Table 3, none of the peptide analogues show a significant passive diffusion transport, as all of them had permeabilities below $2.0 \times 10^{-6} \mathrm{~cm} / \mathrm{s}$ (see Table 3).

Next, to shed light on potential transport of these compounds through the BBB and study whether they are able to cross by active transport, an in vitro cell-based model of the BBB was used (Figure 3). ${ }^{68}$ This human in vitro model of the BBB uses brain-like endothelial cells, generated from human cord blood-derived hematopoietic stem cells cocultured with perycites. Peptide quantification and integrity were analyzed by UPLC and MALDI-TOF, respectively. In this model, Lucifer Yellow lithium salt was used as internal control, whose permeability $\left(P_{\text {app}}\right)$ should stay below $17 \times 10^{-6} \mathrm{~cm} / \mathrm{s}$. In all cases, the integrity of the model was preserved.

Excellent transports were obtained in all cases (ranging from 7.0 to $13.7 \times 10^{-6} \mathrm{~cm} / \mathrm{s}$ ), except for the peptide $20\left(2.7 \times 10^{-6} \mathrm{~cm} / \mathrm{s}\right)$. This compound, in spite of its high degree of similarity with $\mathbf{8}$ (the $\mathrm{N}$-terminal acetylated analogue of $\mathbf{2 0}$ ), showed a 3 -fold reduction in transport, likely to be caused by the action of aminopeptidases (half the peptide was hydrolyzed after $2 \mathrm{~h}$, see mass balance in Table 4 and Supporting Information). Compound stability was preserved in compound 13a, which also contains moiety $\mathbf{2 0}$ at the $C$-erminus.

Thus, the in vitro cell-based human model of the BBB, together with the BBB-PAMPA assay, enabled us to determine that all these compounds are transported by active mechanisms and not through passive diffusion. Moreover, as it is known, the BBB is also an enzymatic barrier, ${ }^{69,70}$ and in this regard we observed an increased resistance to proteases for compounds $\mathbf{8}$ and 13a thanks to the $N$-terminal capping either with an acetyl or the opioid pharmacophore, respectively.

\section{Behavioral Studies in Mice and Rats}

Acute Pain in Mice (Tail-Flick Test)—Evaluation of the antinociceptive potency of hybrid 13a by the tail-flick test in mice after iv administration revealed a maximal effect at 60 min post administration while the maximal effect of morphine was typically reached after 
15-30 min (Figure 4). Compared to morphine, an equipotent effect was measured at much lower doses $(6,31,61 \mathrm{nmol}$ vs morphine in $390 \mathrm{nmol}$ dose). The \%MPE of morphine started to decline from 60 min postadministration, while the nociceptive effect of 13a maintained high \%MPE values for longer periods of time. Longer lasting and maximal effects were measured at 180 and $240 \mathrm{~min}$ for both the 31 and $61 \mathrm{nmol}$ doses (100\%MPE for both doses at both time points and $79.8 \% \mathrm{MPE}$ for $6 \mathrm{nmol}$ dose at $180 \mathrm{~min}$ after administration (data not recorded for morphine at these time-points)). The above results suggested that potent CNS-mediated effects can be obtained by iv injection of hybrid 13a and, hence, BBB permeation did not seem to represent a limitation for this compound as indicated above (cf., in vitro BBB permeability assay). This peptide was modified at the $N$ - and $C$-terminus and internally by the Aba lactam, which should increase its resistance to enzymatic degradation. The stability of 13a in plasma was determined and, to our satisfaction, revealed a half-life time of $585 \mathrm{~min}$ at $37^{\circ} \mathrm{C}$ in human plasma (see Supporting Information).

When hybrid 13a was administered orally to mice at doses of 61, 122, and $196 \mathrm{nmol}$, no analgesic effects were observed (see Supporting Information, no \%MPE > 5\% was observed), even at such high doses.

Neuropathic Pain Tests in Mice-All bifunctional compounds (13a-13d), the parent NOP sequence (20), as well as its $N$-acetylated form $(\mathbf{8})$, were tested in neuropathic pain models in mice. The ligands were all examined as potential suppressors of allodynia and hyperalgesia, phenotypes which were caused by chronic constriction injury to the sciatic nerve (CCI) or by a streptozocin (STZ)-induced type 1 diabetes. ${ }^{71,72}$ The results of these tests are presented in Figure 5 (von Frey test, allodynia) and Figure 6 (cold plate test, hyperalgesia). The calculated $\mathrm{ED}_{50}$ values for the parent compounds and all four hybrids at one time point $(30 \mathrm{~min}$ ) are presented in Table 3 . The results for the parent opioid sequence 7 in mice and rats were obtained during an earlier study. ${ }^{56,73}$

As can be noticed, all bifunctional compounds proved to be significantly more effective than morphine, both in terms of antiallodynic and antihyperalgesic effects. Interestingly and with exception of hybrid $\mathbf{1 3 b}$, the hybrids performed better than the nociceptin parent compounds corresponding to the NOP pharmacophore of 13a (Figures 5 and 6). The hybrids were highly effective at low doses, especially when compared to morphine [e.g., $\mathrm{ED}_{50}(\mathbf{1 3 a})=0.003$ $\mathrm{nmol}$ vs $\mathrm{ED}_{50}($ morphine $)=7 \mathrm{nmol}$, allodynia; $\mathrm{ED}_{50}(\mathbf{1 3 a})=0.004 \mathrm{nmol}$ vs $\mathrm{ED}_{50}$ (morphine) $=7.46 \mathrm{nmol}$, hyperalgesia]. When compared to the opioid parent compound 7 with $\mathrm{ED}_{50}$ values of $0.85 \mathrm{nmol}$ (von Frey) and $1.60 \mathrm{nmol}$ (cold plate), the hybrids were also much more potent. ${ }^{73}$ These observations support the hypothesis that more potent effects can be induced by the presence of both pharmacophores in 13a-13d when compared to the effect of a single opioid or nociceptin unit. The effect of opioid-nociceptin hybrids, in spite of their low NOP antagonist potency, is profound because it originates from the simultaneous modulation of the transmitted signal in the same part of the nociceptive pathway and the influence concerns both endogenous opioid and nociceptin systems which are very important for nociceptive transmission. Moreover, the endogenous nociceptin/ orphanin FQ system, apart from its analgesic action, is known to exhibit anti-opioid activity and may contribute to lower responsiveness to morphine in neuropathic pain. ${ }^{21}$ Therefore, 
simultaneous modulation can cause a much greater change of the input signal than a single compound can evoke. The hybrid strategy offers the advantage over the administration of the two substances which can give way to a different distribution profile.

Nevertheless, also the NOP parent compounds remained effective at low doses, especially with regard to allodynia [e.g., $\mathrm{ED}_{50}(\mathbf{8})=0.008 \mathrm{nmol}, \mathrm{ED}_{50}(\mathbf{2 0})=0.004 \mathrm{nmol}$ ]. The $N$ terminally acetyl-capped parent analogue $\mathbf{8}$ was clearly less potent than the noncapped $\mathbf{2 0}$, which was most pronounced in the cold plate assay [e.g., $\mathrm{ED}_{50}(\mathbf{8})=0.69 \mathrm{nmol}, \mathrm{ED}_{50}(\mathbf{2 0})=$ $0.06 \mathrm{nmol}])$ despite its higher NOP affinity ( $\mathrm{IC}_{50}=0.53 \mathrm{vs} 39 \mathrm{nM}$, Table 2). Both NOP parents (8 and 20) were less potent in the cold plate test (thermal stimulus). Generally, thermal hyperalgesia and tactile allodynia do not correlate neither in mice nor in humans, ${ }^{74}$ and these effects are mediated not only by distinct cellular mechanisms, which is corroborated by a huge amount of data of assorted nature from electrophysiological to clinical observations ${ }^{75}$ but also by different afferent fibers types. ${ }^{76}$

Hybrid 13a seems to be the best of all investigated hybrids, parent peptides, and morphine. The antiallodynic and antihyperalgesic effects of 13a were more prolonged than those produced by a classic analgesic like morphine and stayed extremely high even $180 \mathrm{~min}$ after it administration and injection of very low doses (e.g., $0.0005 \mathrm{nmol}$ ). The effect of the parent compound $\mathbf{2 0}$ is transient, while the acetylated parent $\mathbf{8}$ is efficient at higher doses only ( 0.8 vs 0.05 ). Hybrid 13a is clearly superior (even at very low doses) to the parents in the cold plate test as well as two neuropathy models. Hence, in contrast to common opioids such as morphine, the tested opioid-NOP DMLs exhibit high efficacy in neuropathic pain models. In mice, morphine performs dose-dependently in acute pain, with a dose of $10 \mu \mathrm{g} / \mathrm{animal}$ giving $63.8 \pm 15.9 \% \mathrm{MPE}$ in the tail-flick test. The effect reaches $100 \% \mathrm{MPE}$ upon increased dosing. ${ }^{73}$ On the contrary, under neuropathic conditions, morphine provides 36.5 $\pm 9.5 \% \mathrm{MPE}$ in von Frey test and $30.15 \pm 8.2 \% \mathrm{MPE}$ in cold plate test at the respective dose of $10 \mu \mathrm{g} / \mathrm{animal}$. The effect never reaches maximum values; it sustains at about $50 \% \mathrm{MPE}$ no matter how high the dose is. ${ }^{73}$

Of all hybrids, compound $\mathbf{1 3 b}$ was the least effective [ $\mathrm{ED}_{50}$ of $0.18 \mathrm{nmol}$ (von Frey) and $0.14 \mathrm{nmol}$ (cold plate)] and it only showed a maximal effect, comparable to the other hybrids, at a high dose of $0.5 \mathrm{nmol}$ (Figure 5A and 6A). Hybrids 13c-13d seemed also to be promising compounds in the investigated neuropathic pain models. Taking the results depicted in Figures 5 and 6 into consideration, these analogues presented the most potent and long lasting effects, especially with regard to antiallodynic (von Frey) efficacy.

Altogether, hybrid 13a and 13d seemed to be the most promising compounds in the investigated neuropathic pain models. Taking the results depicted in Figure 5 and 6 into consideration, these analogues presented the most potent and long lasting effects, especially with regard to antiallodynic (von Frey) efficacy (Table 5).

The observations made in the injury-induced neuropathy models also applied to the diabetic neuropathy, although in the latter model the antiallodynic action of the compounds showed a maximum at $30 \mathrm{~min}$ which slightly decreased at $180 \mathrm{~min}$ (Figure 4B). This decrease was also present in the antihyperalgesic action (Figure 5B) except for 13a. This may result from 
intermodel differences in mechanisms underlying the neuropathic symptoms occurrence and maintenance, although it was still promising that 13a was able to alleviate the painful symptoms of both hyperalgesia and allodynia in distinct models. As the discovery of a multifunctional drug alleviating assorted symptoms of neuropathy remains of high interest, the above results provide a worthy outlook toward other novel therapies.

All compounds were also evaluated in the Rota-Rod test to examine motor function of mice. Only the $0.5 \mathrm{nmol}$ dose of $\mathbf{1 3 b}$ gave way to impaired motor function. At the used doses, all other compounds did not impair motor functions (data not shown).

Respiratory Depression in Rats-Respiratory effects in rats were determined by plethysmography after iv administration of equipotent antinociceptive doses (in tail-flick test) of 13a $(0.5 \mathrm{mg} / \mathrm{kg}, 6 \mathrm{nmol} / \mathrm{kg})$ and morphine $(5 \mathrm{mg} / \mathrm{kg}, 390 \mathrm{nmol} / \mathrm{kg})$. On the basis of the measurement of the ventilation minute, administration of 13a did not result in a significant respiratory depression in comparison to saline, a result that stands in contrast to the deleterious effect of morphine ( $p<0.01$; Figure 7F). Interestingly, morphine induced a significant increase in inspiratory time in comparison to saline and 13a $(p<0.05$; Figure 7B), while 13a induced a significant decrease in expiratory time in comparison to morphine $(p<0.05$; Figure 7E). Combining both effects, morphine induced a decrease in respiratory frequency ( $p<0.001$, Figure 7D), while 13a slightly increased this frequency. The tidal volume was significantly reduced with 13a in comparison to saline and morphine $(p<0.05$; Figure 7C).

An increase in inspiratory time is a marker of opioid-related effects on the respiratory control centers in the brainstem. ${ }^{77}$ Remarkably, 13a did not result in any significant increase in inspiratory time at the studied $0.5 \mathrm{mg} / \mathrm{kg}$ dose. Moreover, in comparison to morphine, 13a significantly reduced the expiratory time. Both effects show the limited respiratory effects related to 13a in comparison to the deleterious ones of morphine, studied only at a single therapeutic dose. A more elaborate study will be carried out to compare the ratio of the $\mathrm{ED}_{50} \%$ of the respiratory-to-analgesic effects of $\mathbf{1 3 a}$ versus morphine.

\section{CONCLUSIONS}

In vitro, the opioid-nociceptin hybrids behaved as potent opioid agonists and weak nociceptin antagonists. Although fusion of the two peptide fragments led to a slight loss in opioid and nociceptin receptor binding, low nanomolar affinities were maintained. On the basis of the in vitro evaluation, compound 13a was selected for further in vivo tests. After intravenous administration to naïve mice, it was more active than morphine and showed a prolonged analgesic action $(>3 \mathrm{~h})$ in an acute pain model. This result indicated that hybrid 13a was transported through the BBB, a hypothesis which was further supported by a cellbased in vitro BBB model. In addition, all hybrid compounds were administered intrathecally to CCI mice and were proven to be more effective than morphine and the parent NOP ligands in both antiallodynic and antihyperalgesic effects, with compounds 13a and 13d exhibiting the best in vivo profile. Compared to morphine, the effects of 13a were much more prolonged and extremely high at low doses even at $180 \mathrm{~min}$ postadministration. Because 13a proved to be very potent in both acute and neuropathic pain models, potential 
respiratory depression effects linked to the use of this product were evaluated. Inspiratory and expiratory times show that the administration of 13a did not result in a significant respiratory depression. Altogether, the opioid-NOP hybrids are highly effective analgesics in the investigated neuropathic pain models. The best compounds have $\mathrm{ED}_{50}$ values about 1000 times lower than those of the opioid agonist/NK1 antagonist hybrid H-Dmt-D-Arg-Aba$\beta$-Ala- $M$ Me-Bn( $\left(\mathrm{CF}_{3}\right)_{2}$ in the von Frey test and about 20 times lower in the cold plate test. ${ }^{56,73}$ This shows that opioid-nociceptin hybrids are highly promising compounds as analgesics for the dual treatment of acute and neuropathic pain, devoid of respiratory depression.

\section{MATERIALS AND METHODS}

\section{General}

Thin-layer chromatography (TLC) was performed on glass plates precoated with silica gel $60 \mathrm{~F}_{254}$ (Merck, Darmstadt, Germany) using the mentioned solvent systems. Purification of organic molecules was done with flash chromatography (Davisil LC60A, 40-63 $\mu \mathrm{m}$ ). Mass spectrometry (MS) was performed on a Micromass Q-Tof Micro spectrometer with electrospray ionization (ESI). Data collection and spectrum analysis was done with Masslynx software. Analytical RP-HPLC was performed using a Waters 717plus autosampler, a Waters 1525 binary HPLC pump, and a Waters 2487 dual absorbance wavelength detector (Milford, MA) on a Grace (Deerfield, IL) Vydac RP C18 column (25 $\mathrm{cm} \times 4.6 \mathrm{~mm} \times 5 \mu \mathrm{m}$ ) using UV detection at $215 \mathrm{~nm}$. The mobile phase was a mixture of water and acetonitrile both containing 0.1\% TFA. The used gradient runs from 3 to $100 \%$ acetonitrile in $20 \mathrm{~min}$ at a flow rate of $1 \mathrm{~mL} / \mathrm{min}$. Preparative RP-HPLC purification was done on a Gilson (Middleton, WI) HPLC system with Gilson 322 pumps, controlled by the software package Unipoint and a reversed phase C18 column (DiscoveryBIO SUPELCO Wide Pore C18 column, $25 \mathrm{~cm} \times 2.21 \mathrm{~cm}, 5 \mu \mathrm{m}$ ) using a gradient that increased by $1 \% / \mathrm{min}$ of acetonitrile in water (both containing 0.1\% TFA) until the product eluted. After purification, the purity of all compounds was evaluated as being more than $95 \%$ by analytical RP-HPLC. All fractions were lyophilized using a Flexy-Dry lyophilizer (FTS Systems, Warminster, PA). ${ }^{1} \mathrm{H}$ and ${ }^{13} \mathrm{C}$ NMR spectra were recorded at 500 and $125 \mathrm{MHz}$ on a Bruker Avance II 500 (Bruker Corp, Billerica, MA). Tetramethylsilane (TMS) or residual solvent signals were used as internal standard. The solvent used is mentioned in all cases, and the abbreviations used are as follows: $\mathrm{s}$ (singlet), $\mathrm{d}$ (doublet), dd (double doublet), $\mathrm{t}$ (triplet), q (quadruplet), and m (multiplet).

\section{Synthesis}

General Peptide Synthesis-All peptides were synthesized manually by Fmoc-based solid phase peptide synthesis (SPPS) on Rink amide AM resin. For standard couplings, a 3fold excess of the Fmoc-protected amino acids and 3-fold excess of coupling reagent (HCTU) in 0.4 NMM in DMF was used for $1.5 \mathrm{~h}$. For the coupling of Fmoc-Aba- $\beta$-Ala-OH, 1.5 -fold excess for both the dipeptide and the coupling reagent was used and coupling was left for $3 \mathrm{~h}$. Fmoc deprotection was carried out by treatment of the resin with $20 \% 4-$ methylpiperidine in DMF for 5 and $15 \mathrm{~min}$. After every reaction step, the resin was washed with DMF $(3 \times 1 \mathrm{~min}), \mathrm{PrOH}(3 \times 1 \mathrm{~min})$, and $\mathrm{CH}_{2} \mathrm{Cl}_{2}(3 \times 1 \mathrm{~min})$. 
When the sequence was complete, the peptide was cleaved from the resin and completely deprotected with TFA/TES/ $\mathrm{H}_{2} \mathrm{O}(95: 2.5: 2.5)$ for $3 \mathrm{~h}$. The resin was filtered, and the filtrate was concentrated and added to cold ether. The precipitated peptide was then dissolved in acetonitrile/ $\mathrm{H}_{2} \mathrm{O}$ and lyophilized to get the crude peptides as a powder.

The crude peptides were dissolved in $\mathrm{H}_{2} \mathrm{O}$, and acetonitrile was added until complete dissolution was observed. The solution was injected on a Gilson preparative RP-HPLC. Fractions containing the pure peptide were collected, combined, and lyophilized. The peptides were obtained as white powders with a purity of $>95 \%$ as determined by analytical HPLC. The structures were confirmed by high-resolution electrospray mass spectrometry.

Coupling of the Protected Peptide (11) to the Sixmer (10) (Pathway A)-The protected peptide 11 (1.5 equiv) was dissolved in DMF, and DIC (1.5 equiv) and HOBt (1.5 equiv) were added to the solution. This coupling solution was then added to the resin and shaken for $3 \mathrm{~h}$. No base was added to avoid additional coupling at the unprotected Dmt side chain. After washing with DMF $(3 \times), i \operatorname{PrOH}(3 x)$, and $\mathrm{CH}_{2} \mathrm{Cl}_{2}(3 \times)$, the peptide was cleaved from the resin and purified (See General peptide synthesis).

\section{Peptide Characterization}

Ac-Arg-Tyr-Tyr-Arg-Ile-Lys-NH $\mathbf{2}$ (8): Preparative HPLC yielded the desired compound (white powder, 34\%). HPLC: $t_{\mathrm{R}}=9.4 \mathrm{~min}$. TLC $R_{\mathrm{f}} 0.23(\mathrm{EBAW})$. HRMS $\left(\mathrm{ESP}^{+}\right)$found $\mathrm{m} / z$ $939.5515[\mathrm{M}+\mathrm{H}]^{+}, \mathrm{C}_{44} \mathrm{H}_{71} \mathrm{~N}_{14} \mathrm{O}_{9}{ }^{+}$requires 939.5523 .

H-Dmt-p-Arg-Aba- $\beta$-Ala-Arg-Tyr-Tyr-Arg-Ile-Lys-NH 2 (13a): Preparative HPLC yielded the desired compound (white powder, 25\%). HPLC: $t_{\mathrm{R}}=10.0 \mathrm{~min}$. TLC $R_{\mathrm{f}} 0.60$ (EBAW). HRMS $\left(\mathrm{ESP}^{+}\right.$) found $\mathrm{m} / z 1474.8403[\mathrm{M}+\mathrm{H}]^{+}, \mathrm{C}_{72} \mathrm{H}_{107} \mathrm{~N}_{21} \mathrm{O}_{13}{ }^{+}$requires 1474.8430.

H-Dmt-D-Arg-Aba- $\beta$-Ala-Arg-Tyr-(pF-Phe)-Arg-Trp-Arg-NH 2 (13b): Preparative HPLC yielded the desired compound (white powder, 17\%). HPLC: $t_{\mathrm{R}}=11.2 \mathrm{~min}$. TLC $R_{\mathrm{f}} 0.63$ (EBAW). HRMS $\left(\mathrm{ESP}^{+}\right.$) found $\mathrm{m} / z \mathrm{z} 1577.8538[\mathrm{M}+\mathrm{H}]^{+}, \mathrm{C}_{77} \mathrm{H}_{106} \mathrm{FN}_{24} \mathrm{O}_{12}{ }^{+}$requires 1577.8401 .

H-Dmt-p-Arg-Aba- $\beta$-Ala-Arg-Tyr-Dmt-Arg-Trp-Arg-NH 2 (13c): Preparative HPLC yielded the desired compound (white powder, 23\%). HPLC: $t_{\mathrm{R}}=10.7 \mathrm{~min}$. TLC $R_{\mathrm{f}} 0.61$ (EBAW). HRMS $\left(\mathrm{ESP}^{+}\right.$) found $\mathrm{m} / z 802.4427[\mathrm{M} / 2+\mathrm{H}]^{+}, \mathrm{C}_{79} \mathrm{H}_{111} \mathrm{~N}_{24} \mathrm{O}_{13}{ }^{+} / 2$ requires 802.4418 .

H-Dmt-D-Arg-Aba- $\beta$-Ala-Arg-Tyr-Tyr-Arg-Trp-Arg-NH 2 (13d): Preparative HPLC yielded the desired compound (white powder, 22\%). HPLC: $t_{\mathrm{R}}=10.5 \mathrm{~min}$. TLC $R_{\mathrm{f}} 0.60$ (EBAW). HRMS (ESP ${ }^{+}$) found $\mathrm{m} / \mathrm{z} 788.4251[\mathrm{M} / 2+\mathrm{H}]^{+}, \mathrm{C}_{77} \mathrm{H}_{107} \mathrm{~N}_{24} \mathrm{O}_{13}{ }^{+} / 2$ requires 788.4261 .

H-Arg-Tyr-Tyr-Arg-Ile-Lys- $\mathrm{NH}_{2}$ (20): Preparative HPLC yielded the desired compound (white powder, 33\%). HPLC: $t_{\mathrm{R}}=9.0 \mathrm{~min}$. TLC $R_{\mathrm{f}} 0.07$ (EBAW). HRMS $\left(\mathrm{ESP}^{+}\right.$) found $\mathrm{m} / z$ $897.5428[\mathrm{M}+\mathrm{H}]^{+}, \mathrm{C}_{42} \mathrm{H}_{69} \mathrm{~N}_{14} \mathrm{O}_{8}{ }^{+}$requires 897.5417. 


\section{Synthesis of the Dipeptide Building Blocks}

Fmoc-Aba- $\beta$-Ala-OH (14)—Phth-Aba- $\beta$-Ala-OH 19 (3.91 g, 10.3 mmol, 1 equiv) was dissolved in $110 \mathrm{~mL}$ of ethanol. Hydrazine hydrate $(3.0 \mathrm{~mL}, 62.0 \mathrm{mmol}, 6$ equiv) was added, and the solution was refluxed for $1.5 \mathrm{~h}$, after which the solvent was evaporated. The residue was dissolved in $60 \mathrm{~mL}$ of water, and the $\mathrm{pH}$ was carefully adjusted to $\mathrm{pH} 5$ by dropwise addition of acetic acid and monitoring with a pH meter. The suspension was stirred for $1 \mathrm{~h}$ at room temperature and the phthalhydrazide side-product precipitated. This was filtered off, and the filtrate was evaporated. The residue was dissolved in $100 \mathrm{~mL}$ of a water/acetone mixture. Sodium carbonate ( $261 \mathrm{mg}, 11.4 \mathrm{mmol}, 1.1$ equiv) was added together with Fmoc$\mathrm{OSu}(3.49 \mathrm{~g}, 10.3 \mathrm{mmol}, 1$ equiv) for the Fmoc protection. The reaction mixture was stirred for $16 \mathrm{~h}$. The solvent was evaporated, and the residue was brought to $\mathrm{pH} 2$ with $6 \mathrm{~N} \mathrm{HCl}$.

Ethyl acetate was added, and the phases were separated. The organic phase was washed with a saturated $\mathrm{NaHCO}_{3}$ solution $(3 \times)$ and brine. The residue was purified by column chromatography with $1 \%$ methanol in $\mathrm{CH}_{2} \mathrm{Cl}_{2}(+1 \% \mathrm{AcOH})$ and a yellow solid was obtained in 54\% yield.

Yield: $54 \%$ (2.66 g). Formula: $\mathrm{C}_{28} \mathrm{H}_{26} \mathrm{~N}_{2} \mathrm{O}_{5}$. MW: $470.53 \mathrm{~g} / \mathrm{mol} . R_{\mathrm{f}}=0.75$ (EtOAc $+1 \%$ AcOH). HPLC: $t_{\mathrm{R}}=17.3 \mathrm{~min}$. HRMS $\left(\mathrm{ESP}^{+}\right)$: found $\mathrm{m} / \mathrm{z} 471.1909[\mathrm{M}+\mathrm{H}]^{+}$, $\mathrm{C}_{44} \mathrm{H}_{71} \mathrm{~N}_{14} \mathrm{O}_{9}{ }^{+}$requires 471.1914 ; melting interval, $165.0-170.0{ }^{\circ} \mathrm{C}$ (decomposition). ${ }^{1} \mathrm{H}$ NMR $\left(\mathrm{CDCl}_{3}, 500 \mathrm{MHz}\right): \delta(\mathrm{ppm})=2.32(2 \mathrm{H}, \mathrm{m}), 2.94(1 \mathrm{H}, \mathrm{dd}, J=17.1 \mathrm{~Hz}, J=13.5 \mathrm{~Hz})$, $3.18(1 \mathrm{H}, \mathrm{dd}, J=17.3 \mathrm{~Hz}, J=4.5 \mathrm{~Hz}), 3.56(2 \mathrm{H}, \mathrm{m}), 4.14(1 \mathrm{H}, \mathrm{d}, J=16.7 \mathrm{~Hz}), 4.24(1 \mathrm{H}$, $\mathrm{m}), 4.31(2 \mathrm{H}, \mathrm{m}), 5.08(1 \mathrm{H}, \mathrm{m}), 5.13(1 \mathrm{H}, \mathrm{d}) .{ }^{13} \mathrm{C} \mathrm{NMR}\left(\mathrm{CDCl}_{3}, 125 \mathrm{MHz}\right): \delta(\mathrm{ppm})=33.3$, 35.6, 43.9, 47.1, 50.2, 51.4, 66.3, 120.6, 125.8, 126.4, 127.6, 128.1, 128.1, 129.2, 131.0, 135.2, 135.9, 141.2, 144.4, 156.1, 171.5, 173.0.

Phth-Phe- $\beta$-Ala-OEt (17)—Phthaloyl protected phenylalanine 16 (5 g, 16.9 mmol, 1 equiv) was dissolved in $80 \mathrm{~mL}$ of $\mathrm{CH}_{2} \mathrm{Cl}_{2}$. $\beta$-Alanine ethylester hydrochloride ( $\beta$-AlaOEt.HCl, $2.86 \mathrm{~g}, 18.6 \mathrm{mmol}, 1.1$ equiv) and coupling reagent TBTU (5.98 g, $18.6 \mathrm{mmol}, 1.1$ equiv) were added. $\mathrm{Et}_{3} \mathrm{~N}(7.08 \mathrm{~mL}, 50.8 \mathrm{mmol}, 3$ equiv) was added to the solution, and the $\mathrm{pH}$ was kept at $\mathrm{pH} 8$ by use of $\mathrm{Et}_{3} \mathrm{~N}$. The solution was then stirred for $1 \mathrm{~h}$. The solvent was evaporated, and the residue was dissolved in ethyl acetate. The solution was then washed with $1 \mathrm{~N} \mathrm{HCl}$ solution ( $3 x$ ), saturated $\mathrm{NaHCO}_{3}$ solution ( $3 x$ ), and brine $(3 x)$. The organic phase was dried with $\mathrm{MgSO}_{4}$, filtered, and evaporated. The resulting residue was crystallized from a minimum amount of hot ethanol. After cooling down and filtration, white crystals were obtained with a yield of $70 \%$ after two subsequent crystallizations.

Yield: $70 \%$ (4.649 g, white crystals). Formula: $\mathrm{C}_{22} \mathrm{H}_{22} \mathrm{~N}_{2} \mathrm{O}_{5}$. MW: $394.43 \mathrm{~g} / \mathrm{mol} . R_{\mathrm{f}}=0.56$ (EtOAc/petroleum ether 1:1). HPLC: $t_{\mathrm{R}}=15.9 \mathrm{~min}$. MS (ES+): $395[\mathrm{M}+\mathrm{H}]^{+}, 349[\mathrm{M}-$ $\mathrm{OEt}]^{+}$; melting interval, $121.1-121.9{ }^{\circ} \mathrm{C} .{ }^{1} \mathrm{H} \mathrm{NMR}\left(\mathrm{CDCl}_{3}, 500 \mathrm{MHz}\right): \delta(\mathrm{ppm})=1.23(3 \mathrm{H}$, $\mathrm{t}, J=7.1 \mathrm{~Hz}), 2.53(2 \mathrm{H}, \mathrm{m}), 3.54(4 \mathrm{H}, \mathrm{m}), 4.09(2 \mathrm{H}, \mathrm{q}, J=7.1 \mathrm{~Hz}), 5.08(1 \mathrm{H}, \mathrm{dd}, J=10.4$ $\mathrm{Hz}, J=6.3 \mathrm{~Hz}), 6.70(1 \mathrm{H}, \mathrm{m}), 7.04-7.23(5 \mathrm{H}, \mathrm{m}), 7.63-7.82(4 \mathrm{H}, \mathrm{m}) .{ }^{13} \mathrm{C} \mathrm{NMR}\left(\mathrm{CDCl}_{3}\right.$, $125 \mathrm{MHz}): \delta(\mathrm{ppm})=14.1,33.7,34.7,35.2,55.7,60.8,123.5,126.9,128.6,128.9,131.4$, $134.2,136.7,167.8,168.4,172.5$. 
Phth-Aba- $\beta$-Ala-OEt (18) - In a two-neck flask, equipped with a Dean-Stark apparatus, $\mathrm{P}_{2} \mathrm{O}_{5}$ (10 g, $70.5 \mathrm{mmol}, 11.1$ equiv), $85 \% \mathrm{H}_{3} \mathrm{PO}_{4}(6.5 \mathrm{~mL}, 95.0 \mathrm{mmol}, 15$ equiv), $100 \mathrm{~mL}$ of acetic acid, and $150 \mathrm{~mL}$ of benzene were mixed. The solution was refluxed for $30 \mathrm{~min}$, then the starting material 17 ( $2.5 \mathrm{~g}, 6.34 \mathrm{mmol}, 1$ equiv) and trioxane ( $3.75 \mathrm{~g}, 41.6 \mathrm{mmol}, 6.6$ equiv) were added. The mixture was refluxed until completion of the reaction $(4 \mathrm{~h})$ and every $30 \mathrm{~min}$, trioxane ( $3.75 \mathrm{~g}, 41.6 \mathrm{mmol}, 6.6$ equiv) was added. After $2 \mathrm{~h}, \mathrm{P}_{2} \mathrm{O}_{5}(10.0 \mathrm{~g}$, $70.5 \mathrm{mmol}, 11.1$ equiv) was added. After completion, benzene was evaporated and the residue was diluted with ether. This mixture was washed three times with $1 \mathrm{~N} \mathrm{HCl}$, saturated $\mathrm{NaHCO}_{3}$, and brine. The organic phase was dried, filtered, and evaporated to obtain a yellow oil. This residue was then purified with flash chromatography with 30\% EtOAc in petroleum ether to yield a yellow oil in $65 \%$.

Yield: $65 \%$ (1.68 g). Formula: $\mathrm{C}_{23} \mathrm{H}_{22} \mathrm{~N}_{2} \mathrm{O}_{5}$. MW: $406.44 \mathrm{~g} / \mathrm{mol} . R_{\mathrm{f}}=0.61$ (EtOAc/ petroleum ether 1:1). HPLC: $t_{\mathrm{R}}=16.6 \mathrm{~min}$. MS $(\mathrm{ES}+): 407[\mathrm{M}+\mathrm{H}]^{+}, 429[\mathrm{M}+\mathrm{Na}]^{+}, 361$ $[\mathrm{M}-\mathrm{OEt}]^{+} .{ }^{1} \mathrm{H} \mathrm{NMR}\left(\mathrm{CDCl}_{3}, 500 \mathrm{MHz}\right): \delta(\mathrm{ppm})=1.22(3 \mathrm{H}, \mathrm{t}, J=7.2 \mathrm{~Hz}), 2.62(2 \mathrm{H}, \mathrm{m})$, $3.12\left(1 \mathrm{H}, \mathrm{dd}, J=15.6 \mathrm{~Hz},{ }^{3} J=4.7 \mathrm{~Hz}\right), 3.74(1 \mathrm{H}, \mathrm{m}), 3.89(1 \mathrm{H}, \mathrm{m}), 4.11(3 \mathrm{H}, \mathrm{m}), 4.71(1 \mathrm{H}$, d, $J=15.8 \mathrm{~Hz}), 4.78\left(1 \mathrm{H}, \mathrm{d},{ }^{2} J=15.9 \mathrm{~Hz}\right), 5.36(1 \mathrm{H}, \mathrm{dd}, J=13.1 \mathrm{~Hz}, J=4.9 \mathrm{~Hz}), 7.25-7.30$ $(4 \mathrm{H}, \mathrm{m}), 7.75(2 \mathrm{H}, \mathrm{m}), 7.89(2 \mathrm{H}, \mathrm{m}) .{ }^{13} \mathrm{C} \mathrm{NMR}\left(\mathrm{CDCl}_{3}, 125 \mathrm{MHz}\right): \delta(\mathrm{ppm})=14.1,33.2$, 34.1, 46.6, 52.0, 53.0, 60.7, 123.5, 127.1, 128.5, 128.7, 130.0, 132.0, 134.1, 135.6, 135.9, 168.0, 168.6, 172.0.

Phth-Aba- $\beta$-Ala-OH (19)—Phth-Aba- $\beta$-Ala-OEt 18 (4.74 g, 11.7 mmol, 1 equiv) was dissolved in $60 \mathrm{~mL}$ of acetone. Then $60 \mathrm{~mL}$ of a $1 \mathrm{~N} \mathrm{HCl}$ solution was slowly added. The mixture was refluxed in an oil bath at $90^{\circ} \mathrm{C}$ for $16 \mathrm{~h}$ and then cooled to room temperature, and the solvent was evaporated. A white solid was obtained in $89 \%$ yield and was used in the next step without purification.

Yield: 89\% (3.91 g). Formula: $\mathrm{C}_{21} \mathrm{H}_{18} \mathrm{~N}_{2} \mathrm{O}_{5}$. MW: $378.38 \mathrm{~g} / \mathrm{mol} . R_{\mathrm{f}}=0.62$ (EtOAc $+1 \%$ AcOH). HPLC: $t_{\mathrm{R}}=15.7 \mathrm{~min}$. MS (ES+): $379[\mathrm{M}+\mathrm{H}]^{+}, 401[\mathrm{M}+\mathrm{H}]^{+}, 417[\mathrm{M}+\mathrm{K}]^{+}$; melting interval, $201.5-203.0{ }^{\circ} \mathrm{C} .{ }^{1} \mathrm{H}$ NMR $\left(\mathrm{CDCl}_{3}, 500 \mathrm{MHz}\right): \delta(\mathrm{ppm})=2.68(2 \mathrm{H}, \mathrm{m})$, $3.10(1 \mathrm{H}, \mathrm{dd}, J=15.5 \mathrm{~Hz}, J=4.8 \mathrm{~Hz}), 3.72(1 \mathrm{H}, \mathrm{m}), 3.88(1 \mathrm{H}, \mathrm{m}), 4.11(1 \mathrm{H}, \mathrm{dd}, J=15.5$ $\mathrm{Hz}, J=13.7 \mathrm{~Hz}), 4.73(2 \mathrm{H}$, pseudo-s), $5.32(1 \mathrm{H}, \mathrm{dd}, J=13.0 \mathrm{~Hz}, J=4.9 \mathrm{~Hz}), 7.22-7.32$ $(4 \mathrm{H}, \mathrm{m}), 7.73(2 \mathrm{H}, \mathrm{m}), 7.87(2 \mathrm{H}, \mathrm{m}) .{ }^{13} \mathrm{C} \mathrm{NMR}\left(\mathrm{CDCl}_{3}, 125 \mathrm{MHz}\right): \delta(\mathrm{ppm})=32.9,34.2$, 46.6, 52.1, 53.2, 123.6, 127.3, 128.4, 128.8, 130.0, 132.0, 134.2, 135.6, 135.8, 167.9, 168.8, 175.7.

\section{In Vitro Biological Evaluation}

\section{In Vitro Affinity}

Radioligand Binding Assays: Membranes from HEK293 cells transiently expressing human MOP, DOP, and KOP, as well as NOP, were obtained as previously reported. ${ }^{52,78}$ All membrane preparations were stored at $-80{ }^{\circ} \mathrm{C}$ as aliquots $(1 \mathrm{mg}$ protein $/ \mathrm{mL})$ until use. Following their dilution in $50 \mathrm{mM}$ Tris-HCl buffer $(\mathrm{pH} 7.4)$ supplemented with $0.1 \%$ BSA, opioid receptor-containing membranes were incubated for $1 \mathrm{~h}$ at $25^{\circ} \mathrm{C}$ with $\left[{ }^{3} \mathrm{H}\right]$ Diprenorphine (0.6 nM; MOP, DOP, and KOP) or $\left[{ }^{3} \mathrm{H}\right] \mathrm{OFQ} /$ nociceptin $(0.15 \mathrm{nM}$; NOP) and increasing concentrations of compounds to be tested in a final volume of $0.2 \mathrm{~mL}$. 
Nonspecific binding was defined in the presence of $10 \mu \mathrm{M}$ naloxone (MOP, DOP, and KOP) or $\mathrm{OFQ} /$ nociceptin (NOP). Membrane-bound radioactivity was separated from free radioligand by rapid filtration through a 96-well GF/B unifilter apparatus (PerkinElmer Life and Analytical Sciences, Courtaboeuf, France) and quantified using a TopCount scintillation counter (PerkinElmer).

cAMP Accumulation: The agonist/antagonist nature of MOP/NOP hybrids at NOP was examined by using the GloSensor cAMP assay according to manufacturer recommendations (Promega, Madison WI, USA) with a few modifications. HEK293 cells selected for stable expression of human NOP and GloSensor were harvested from culture dishes and suspended $\left(10^{6}\right.$ cells per $\mathrm{mL}$ ) in physiological Hepes buffer ( $10 \mathrm{mM}$ HEPES, $0.4 \mathrm{mM} \mathrm{NaH}_{2} \mathrm{PO}_{4}, 137.5$ $\mathrm{mM} \mathrm{NaCl}, 1.25 \mathrm{mM} \mathrm{MgCl}_{2}, 1.25 \mathrm{mM} \mathrm{CaCl}_{2}, 6 \mathrm{mM} \mathrm{KCl}, 10 \mathrm{mM}$ glucose, and $1 \mathrm{mg} / \mathrm{mL}$ bovine serum albumin, $\mathrm{pH}$ 7.4) supplemented with $1 \mathrm{mM}$ D-luciferin. Following preequilibration for $2 \mathrm{~h}$ at $25^{\circ} \mathrm{C}$, o-luciferin-loaded HEK cells were distributed (100000 cells per well) in white 96-well Greiner plates (Courtaboeuf, France) and kinetic recordings of their luminescence level were acquired using a FlexStation II. In the agonist mode, compounds to be tested were injected at various concentrations $15 \mathrm{~min}$ before forskolin addition ( $0.5 \mu \mathrm{M}$ final concentration) and readings were pursued for $90 \mathrm{~min}$. In the antagonist mode, different concentrations of compounds to be tested were preincubated with cells for $15 \mathrm{~min}$ before the addition of various concentrations of $\mathrm{OFQ} /$ nociceptin.

Experiments were conducted at $25^{\circ} \mathrm{C}$ in the presence of $0.5 \mathrm{mM}$ IBMX to prevent the degradation of cAMP by phospodiesterases. $\mathrm{p} A_{2}$ values were obtained by analyzing the antagonist-induced rightward shifts of dose-response curves according to the Arunlakshana and Schild equation: ${ }^{79} \log (\mathrm{DR}-1)=s \log [\mathrm{B}]-\log K$, where dose ratios DR $\left(\mathrm{EC}_{50, \mathrm{obs}} /\right.$ $\mathrm{EC}_{50 \text {,cont }}$ ) serve to quantify midpoint shifts at each antagonist concentration [B], $K$ is an estimate of antagonist potency, and $\mathrm{s}$ is the Schild slope. A $\mathrm{p} A_{2}$ value for the antagonist was estimated via the $\mathrm{p} A_{2}=\mathrm{p} K / \mathrm{s}$ relationship.

In Vitro Activity: Functional Guinea Pig Ileum (GPI) and Mouse Vas Deferens (MVD) Assays: The GPI and MVD bioassays were carried out as described in detail elsewhere. ${ }^{80,81}$ A dose-response curve was determined with [ $\left.\mathrm{Leu}^{5}\right]$ enkephalin as standard for each ileum and vas preparation, and $\mathrm{IC}_{50}$ values of the compounds being tested were normalized according to a published procedure. ${ }^{82}$

Parallel Artificial Membrane Permeability Assay (PAMPA): The PAMPA assay was used to determine passive diffusion capacity across the BBB. The assay was performed as described previously. ${ }^{83}$ Compounds were dissolved with the System Solution (pION) containing 20\% 1-propanol ( $1 \mathrm{~mL}$ ) at a concentration of $500 \mu \mathrm{M}$. Propranolol was used as a positive control. Stirring magnets were added in the donor compartment, and $195 \mu \mathrm{L}$ of each compound was added then to donor compartments. Subsequently, $4 \mu \mathrm{L}$ of a phospholipid mixture (Porcine Brain Polar Lipid Extract from Avantis Polar Lipids; $20 \mathrm{mg} / \mathrm{mL}$ in dodecane) was added to the membrane, located at the bottom of the acceptor compartments. This phospholipid mixture comprised phosphatidylcholine (PC; 12.6\%), phosphatidylethanolamine (PE; 33.1\%), phosphatidylserine (PS; 18.5\%), phosphatidylinositol (PI; 4.1\%), phosphatidic acid (0.8\%), and other compounds (30.9\%). 
Acceptor wells were placed above the donor plate and filled with $200 \mu \mathrm{L}$ of System Solution (20\% 1-propanol). The PAMPA plate (pION) was placed into a GUTBOX (containing wet sponges) for $4 \mathrm{~h}$ at room temperature. Agitation was maintained in $25 \mu \mathrm{m}$ of unstirred water layer (UWL). Compounds were then quantified by RP-HPLC and identified by MALDITOF. Effective permeability was calculated as shown in eq 1 :

$$
P_{\mathrm{e}}=\frac{-218.3}{t} \log \left(1-\frac{2 C_{\mathrm{A}}(t)}{C_{\mathrm{D}}\left(t_{0}\right)}\right) \times 10^{-6} \mathrm{~cm} / \mathrm{s}
$$

In Vitro Human BBB Cell-Based Model Assay: This assay was performed using the model developed by Cecchelli and co-workers. ${ }^{68}$ Endothelial cells and pericytes were defrosted in gelatin-coated Petri dishes (Corning). Pericytes and endothelial cells were cultured in DMEM pH 6.8 or in supplemented endothelial cell growth medium (Sciencells), respectively. After $48 \mathrm{~h}$, pericytes (50000 cells/well) and endothelial cells (80000 cells/well) were seeded in gelatin-coated 12-well plates or in Matrigel-coated 12-well Transwell inserts (Corning), respectively. Medium was changed every 2-3 days, and assays were performed $7-8$ days after seeding. Lucifer Yellow $(50 \mu \mathrm{M})$ was used as internal control $\left(P_{a p p}<15 \times\right.$ $10^{-6} \mathrm{~cm} / \mathrm{s}$ ), and LY fluorescence was measured in a 96-well plate with a Fluoroskan Ascent microplate fluorometer (Thermo Fisher Scientific).

Compounds were dissolved in Ringer Hepes at the final concentration of $200 \mu \mathrm{M}$. Then, 500 $\mu \mathrm{L}$ of the compound and $1500 \mu \mathrm{L}$ of Ringer HEPES alone were introduced in the apical or in the basolateral compartments, respectively. The plates were set on at $37{ }^{\circ} \mathrm{C}$ for $2 \mathrm{~h}$. The solutions from both compartments were then recovered and quantified by UPLC and identified by UPLC-MS and MALDI-TOF. Apparent permeability was calculated using eq 2:

$$
P_{\text {app }}=\frac{\mathrm{d} Q_{\mathrm{A}}(t)}{\mathrm{d} t} \frac{1}{A} \frac{1}{Q_{\mathrm{D}}\left(t_{0}\right)} V_{\mathrm{D}}
$$

\section{Behavioral Study in Mice}

Animals-The male mice strain C57BL6 (20-25g), obtained from the Animal House Mossakowski Medical Research Centre, Polish Academy of Sciences, were housed 4-5 mice per cage in cages lined with sawdust. Animals was maintained under standard room temperature $22 \pm 2{ }^{\circ} \mathrm{C}$, humidity $50 \pm 5 \%, 12 / 12 \mathrm{~h}$ light-dark cycle, with unlimited access to food and water. All experimental procedures were approved by The Local Committee for Ethics in Animal Experiments (permission number: 14/2013).

Acute Pain in Mice (Tail-Flick Test)—Analgesic activity of the compounds was measured on male mice strain C57BL6 in the tail-flick test. These experiments were conducted using a plantar test and Tail Flick Analgesia Meter apparatus (IITC Life Science Inc., USA), where a light beam is used as a thermal nociceptive stimulus. First, the mouse was restrained and either tested compound or saline (used as a control group) was administered by intravenous injection to the tail vain. During the measurements, the radiant 
heat was applied to the ventral side of animals' tail and the time latency for withdrawal or shaking of the tail was recorded. Measurements were performed before drugs administration (baseline) and at following time-points of 5, 15, 30, 60, and 120 min after injection. A cutoff of $10 \mathrm{~s}$ was set in the tail flick test in order to avoid tissue damage. Responses are expressed as a percentage of the maximum possible effect (\%MPE) which is calculated as [ $\left(T_{1}\right.$ $\left.\left.T_{0}\right) /\left(T_{2}-T_{0}\right)\right] \times 100$, where $T_{0}$ and $T_{1}$ are the tail-flick latencies before and after drug injection respectively and $T_{2}$ is the cutoff time. Drug-treated and saline-treated (control) groups consisted of $8-10$ mice each. The significance is given in the graphs (no significance $P>0.05$, significant $* P<0.05$, ** $P<0.01$, *** $P<0.001)$.

\section{Neuropathic Pain}

Animals-Male Albino Swiss CD-1 IGS mice (30-35 g) obtained from Charles River Breeding Laboratories, Germany, were housed six per cage in cages lined with sawdust under a standard 12/12 h light/dark cycle (lights on at 6:00 am) with food and water available ad libitum. All experiments were performed according to the recommendations of IASP, the NIH Guide for Care and Use of Laboratory Animals, and were approved by the local Bioethics Committee (Krakow, Poland).

Chronic Constriction Injury in Mice-Chronic constriction injury (CCI) model was performed according to Bennet and $\mathrm{Xie}^{84}$ and was modified for mice by Mika (2007). ${ }^{85}$ Mice were preanaesthetized with chloral hydrate $(500 \mathrm{mg} / \mathrm{kg}$ ip) to prolong and deepen anesthesia state. The surgical procedure was performed under isoflurane anesthesia. An incision was made below the mouse's right hipbone, and the sciatic nerve was exposed. Three ligatures with $4 / 0$ silk thread were made around the nerve distal to the sciatic notch with $1 \mathrm{~mm}$ spacing until a brief twitch in the respective hind limb was observed. After 7 days of recovery, mice were tested to assess neuropathy development. All CCI mice developed allodynia and hyperalgesia. Main experiments were conducted on days 7-16 after CCI surgical procedure.

Type 1 Diabetes Model in Mice-The type 1 diabetes model was obtained by a single intraperitoneal (ip) injection of streptozocin (STZ; $200 \mathrm{mg} / \mathrm{kg}$; Sigma-Aldrich, USA) prepared in water for injection (Polpharma, Poland). The glucose concentration was measured in blood collected from the tail vein. Mice with serum glucose levels above 300 $\mathrm{mg} / \mathrm{dL}$ were considered diabetic. Mice that did not develop diabetes, or allodynia and hyperalgesia, were excluded from the study. The behavioral tests were conducted on day 10 after STZ injection.

Drugs Administration-Drugs were dissolved in water for injection (Polpharma, Poland) and administered intrathecally (it) in $5 \mu \mathrm{L}$ dose volume through lumbar puncture between L5 and L6 to non-anesthetized mice according to upgraded Hylden and Wilcox ${ }^{86}$ model described with modifications by Fairbanks. ${ }^{87}$ The it injections were performed with disposable 30 gauge $1 / 2$ in. needles (Becton Dickinson and Company, Rutherford, NJ, U.S.A.) matched to a $25 \mu \mathrm{L}$ syringe (Hamilton, Reno, NV, USA). The von Frey and cold plate tests were performed at 30, 90, and 180 min after drug administration, while Rota Rod test was performed at 15 and $120 \mathrm{~min}$. 


\section{Behavioral Tests in Mice}

Von Frey Test: Mechanical sensitivity to non-noxious stimuli was measured by applying a set of calibrated nylon monofilaments (0.6-6 g; Stoelting) in serial increments on a tested hind paw plantar surface until a behavioral response was observed. Response considered as pain behavior included paw withdrawal, shaking, and licking. In the von Frey test, results are expressed as pressure $[\mathrm{g}]$ applied with a calibrated plastic filament to the midplantar surface of the mouse's injured hind paw (cutoff: $6 \mathrm{~g}$ ), which elicited a foot withdrawal response.

Cold Plate Test: Sensitivity to noxious thermal stimuli was assessed with usage of Cold/Hot Plate Analgesia Meter, Columbus Instruments. The temperature of the plate was kept at $2{ }^{\circ} \mathrm{C}$, and the cutoff latency was $30 \mathrm{~s}$. The mice were placed on the cold plate, and the time until the hind paw was lifted is recorded. The lifting of the injured hind paw in the CCI model, or reaction of one of the hind paws in the STZ model were considered as a reaction to noxious cold stimulus.

Rota Rod Test: To assess motor coordination, Rota Rod 47600 for mice was used (Ugo Basile, Italy). Mice were placed on a horizontal rod which is rotating at accelerating speed, starting with $2 \mathrm{rpm}$ and reaching $40 \mathrm{rpm}$ within $300 \mathrm{~s}$ (cutoff). The experiment was conducted after three training sessions with minimum 15 min pause between each session. The time was recorded until a mouse fell off the rod.

Respiratory Depression-All the experimental protocols were carried out within the ethical guidelines established by the European Union Legislation. Protocols were approved by the local ethics committee for animal experimentation of Paris-Descartes University.

Animals-Male Sprague-Dawley rats (Janvier, France) weighing between 250 and $350 \mathrm{~g}$ at the time of experimentation were used. Animals were housed for 7 days before experimentation in an environment maintained at $21 \pm 0.5{ }^{\circ} \mathrm{C}$ with controlled humidity and light-dark cycle (lights on between 08:00 and 20:00). Food and tap water were provided ad libitum.

Drugs-Morphine sulfate was purchased from Francopia, France, diluted in $0.9 \% \mathrm{NaCl}$ to obtain a solution of $3.5 \mathrm{mg} / \mathrm{mL}$.

Jugular Catheterization-One week before the study, the rat jugular vein was catheterized using $20 \mathrm{~cm}$ silastic tubing with external and internal diameters of 0.94 and $0.51 \mathrm{~mm}$, respectively (Dow Corning Co., Midland, MI). Catheter was tunneled subcutaneously and fixed at the back of the neck. Heparinized saline was injected into the catheter to avoid thrombosis and catheter obstruction. Rats were then returned to their individual cages for a recovery period of 7 days, allowing complete anesthesia washout. On the day of experimentation, rats were placed in horizontal Plexiglas cylinders $(6.5 \mathrm{~cm}$ internal diameter, up to $20 \mathrm{~cm}$ adjustable length) (Harvard Apparatus, Inc., Holliston, MA, USA), modified by the addition of several holes at the cephalic end to avoid $\mathrm{CO}_{2}$ rebreathing. Before drug administration, the catheter was exteriorized, purged, and its permeability checked. 
Respiratory Effects Measurement Using the Whole Body PlethysmographyFour days before the study, temperature transmitters (TA-F10, DSI, Chatillon, France) were implanted in the peritoneal cavity. Ventilatory parameters were recorded in a whole body plethysmograph by the barometric method described and validated in the rat. ${ }^{88}$ The first measurement was performed after a 30 min period of accommodation, while the animal was quiet and not in deep or rapid eye movement sleep, as roughly estimated from their behavior, response to noise, and pattern of breathing. Then, the animal was gently removed from the chamber for iv injection of the tested drug at $T_{0}$ and replaced in the chamber for the remaining measurements. Ventilation was recorded at $-30,-15,-5,5,10,15,30,45,60,90$, and $120 \mathrm{~min}$, each record lasting about $60 \mathrm{~s}$. The following parameters were measured: the tidal volume $\left(V_{\mathrm{T}}\right)$, the inspiratory time $\left(T_{\mathrm{I}}\right)$, the expiratory time $\left(T_{\mathrm{E}}\right)$, and the respiratory cycle duration $\left(T_{\mathrm{TOT}}=T_{\mathrm{I}}+T_{\mathrm{E}}\right)$. Additional parameters were calculated: the respiratory frequency $(f)$ and the minute volume $\left(V_{\mathrm{E}}=V_{\mathrm{T}} \times f\right)$. $T_{0}$ values were the mean of the three baseline measurements.

Study Design—Rats were randomized into three groups receiving iv $0.9 \% \mathrm{NaCl}$, morphine $(5 \mathrm{mg} / \mathrm{kg})$ or $13 \mathbf{a}(0.5 \mathrm{mg} / \mathrm{kg})$ to investigate antinociception $(N=7)$ and respiratory effects $(N=6)$.

\section{Data Analysis}

Results are expressed as mean \pm SEM. To permit simultaneous analysis of the effect of time and treatments on \%MPE and plethysmography parameters, for each animal and for each studied parameter, the area under the curve (AUC) from $T_{0}$ to the completion of the measurement (240 and 120 min, respectively) was calculated using the trapezoid method. For each parameter, we compared the AUCs using Kruskal-Wallis tests for comparisons between the three groups. All tests were performed using Prism version 6.0 (GraphPad Software, Inc., San Diego, CA), and P-values of less than 0.05 were considered as significant.

\section{Supplementary Material}

Refer to Web version on PubMed Central for supplementary material.

\section{Acknowledgments}

We thank Yannick van Wanseele and Dr. Ann Van Eeckhaut for the determination of plasma stability for compound 13a. The work of J.S., E.R., J.M., and B.P. was supported by a MAESTRO NCN2012/06/A/NZ4/00028; statutory funds; J.S. is a holder of KNOW scholarship sponsored by Ministry of Science and Higher Education, Poland. The work of M.T. and P.A. was supported by MINECO-FEDER (BIO2013-40716-R). V.U. and F.S. were supported by CNRS, Strasbourg University and LABEX ANR-10-LABX-0034-Medalis and received financial support from the French government managed by "Agence Nationale de la Recherche" under "Programme d'investissement d'avenir". The work of P.W.S. was supported by NIH grants DA004443 and DA015353, and by CIHR grant MOP-89716.

\section{ABBREVIATIONS USED}

\%MPE percent of maximal possible effect 


\begin{tabular}{|c|c|}
\hline Aba & 4-amino-2-benzazepinone \\
\hline cAMP & 3',5'-cyclic adenosine monophosphate \\
\hline CCI & chronic constriction injury to the sciatic nerve \\
\hline DIC & $N, N$-dicyclohexylcarbodiimide \\
\hline DMF & $N, N$-dimethylformamide \\
\hline DML & designed multiple ligand \\
\hline Dmt & 2',6'-dimethyl-L-tyrosine \\
\hline DOP & $\delta$-opioid receptor \\
\hline EBAW & ethyl acetate/ $n$-butanol, acetic acid/water \\
\hline FSK & forskolin \\
\hline GPI & guinea pig ileum \\
\hline HOBt & 1-hydroxybenzotriazole; i \\
\hline it & intrathecal \\
\hline iv & intravenous \\
\hline KOP & $\kappa$-opioid receptor \\
\hline MOP & $\mu$-opioid receptor \\
\hline MVD & mouse vas deferens \\
\hline NMM & $N$-methylmorpholine \\
\hline NOP & nociceptin receptor \\
\hline PAMPA & parallel artificial membrane permeability assay \\
\hline Pbf & 2,2,4,6,7-pentamethyldihydrobenzofuran-5-sulfonyl \\
\hline $\mathbf{P C}$ & phosphatidylcholine \\
\hline $\mathbf{P E}$ & phosphatidylethanolamine \\
\hline pF-Phe & para-fluoro-phenylalanine \\
\hline PI & phosphatidylinositol \\
\hline RP-HPLC & reversed phase high pressure liquid chromatography \\
\hline PS & phosphatidylserine \\
\hline SD & standard deviation \\
\hline SPPS & solid phase peptide synthesis \\
\hline STZ & streptozotocin \\
\hline HCTU & $\begin{array}{l}O \text {-(6-chlorobenzotriazol-1-yl)- } N, N, N^{\prime}, N \text {-tetramethyluronium } \\
\text { hexafluorophosphate }\end{array}$ \\
\hline
\end{tabular}


triethylsilane

\section{REFERENCES}

1. Breivik H, Collett B, Ventafridda V, Cohen R, Gallacher D. Survey of Chronic Pain in Europe: Prevalence, Impact on Daily Life, and Treatment. Eur. J. Pain. 2006; 10:287-333. [PubMed: 16095934]

2. Kalso E, Edwards JE, Moore RA, McQuay HJ. Opioids in Chronic Non-cancer Pain: Systematic Review of Efficacy and Safety. Pain. 2004; 112:372-380. [PubMed: 15561393]

3. Porreca F, Ossipov MH. Nausea and Vomiting Side Effects with Opioid Analgesics during Treatment of Chronic Pain: Mechanisms, Implications, and Management Options. Pain Med. 2009; 10:654-662. [PubMed: 19302436]

4. Wikler A, Frank K. Hindlimb Reflexes of Chronic Spinal Dogs during Cycles of Addiction to Morphine and Methadon. J. Pharmacol. Exp. Ther. 1948; 94:382-400. [PubMed: 18105656]

5. Martin WR, Eades CG. A Comparison between Acute an Chronic Physical Dependence in the Chronic Spinal Dog. J. Pharmacol. Exp. Ther. 1964; 146:385-394. [PubMed: 14254334]

6. Cochin J, Kornetsky C. Development and Loss of Tolerance to Morphine in the Rat after Single and Multiple Injections. J. Pharmacol. Exp. Ther. 1964; 145:1-10. [PubMed: 14209505]

7. Pattinson KT. Opioids and the Control of Respiration. Br. J. Anaesth. 2008; 100:747-758. [PubMed: 18456641]

8. Dart RC, Surratt HL, Cicero TJ, Parrino MW, Severtson SG, Bucher-Bartelson B, Green JL. Trends in Opioid Analgesic Abuse and Mortality in the United States. N. Engl. J. Med. 2015; 372:241-248. [PubMed: 25587948]

9. Mowry JB, Spyker DA, Cantilena LR, McMillan N, Ford M. 2013 Annual report of the American Association of Poison Control Centers' National Poison Data System (NPDS): 31st Annual Report. Clin. Toxicol. 2014; 52:1032-1283.

10. Powell KJ, Quirion R, Jhamandas K. Inhibition of Neurokinin-1-Substance P Receptor and Prostanoid Activity Prevents and Reverses the Development of Morphine Tolerance in vivo and the Morphine-induced Increase in CGRP Expression in Cultured Dorsal Root Ganglion Neurons. Eur. J. Neurosci. 2003; 18:1572-1583. [PubMed: 14511336]

11. Boules M, Johnston H, Tozy J, Smith K, Li Z, Richelson E. Analgesic Synergy of Neurotensin Receptor Subtype 2 Agonist NT79 and Morphine. Behav. Pharmacol. 2011; 22:573-581. [PubMed: 21691202]

12. Yano K, Kimura S, Imanishi Y. Simultaneous Activation of Two Different Receptor Systems by Enkephalin/Neurotensin Conjugates Having Spacer Chains of Various Lengths. Eur. J. Pharm. Sci. 1998; 7:41-48. [PubMed: 9845776]

13. Tian J-H, Xu W, Fang Y, Mogil JS, Grisel JE, Grandy DK, Han J-S. Bidirectional Modulatory Effect of Orphanin FQ on Morphine-induced Analgesia: Antagonism in Brain and Potentiation in Spinal Cord of the Rat. Br. J. Pharmacol. 1997; 120:676-680. [PubMed: 9051307]

14. Mollereau C, Parmentier M, Mailleux P, Butour JL, Moisand C, Chalon P, Caput D, Vassart G, Meunier JC. ORL1, a Novel Member of the Opioid Receptor Family. Cloning, Functional Expression and Localization. FEBS Lett. 1994; 341:33-38. [PubMed: 8137918]

15. Cox, B.; Chavkin, C.; Christie, M.; Civelli, O.; Evans, C.; Hamon, M.; Hoelt, V.; Kieffer, B.; Kitchen, I.; McKnight, A.; Meunier, JC.; Portoghese, P. Opioid Receptors. In: Girdlestone, D., editor. The IUPHAR Compendium of Receptor Characterization and Classification. London: IUPHAR Media Ltd; 2000. p. 321-333.

16. Lambert DG. The Nociceptin/Orphanin FQ Receptor: a Target with Broad Therapeutic Potential. Nat. Rev. Drug Discovery. 2008; 7:694-710. [PubMed: 18670432]

17. Mogil JS, Pasternak GW. The Molecular and Behavioral Pharmacology of the Orphanin FQ/ Nociceptin Peptide and Receptor Family. Pharmacol. Rev. 2001; 53:381-415. [PubMed: 11546835] 
18. Andoh T, Itoh M, Kuraishi Y. Nociceptin Gene Expression in Rat Dorsal Root Ganglia Induced by Peripheral Inflammation. NeuroReport. 1997; 8:2793-2796. [PubMed: 9295119]

19. Jia Y, Linden DR, Serie JR, Seybold VS. Nociceptin/Orphanin FQ Binding Increases in Superficial Laminae of the Rat Spinal Cord during Persistent Peripheral Inflammation. Neurosci. Lett. 1998; 250:21-24. [PubMed: 9696056]

20. Briscini L, Corradini L, Ongini E, Bertorelli R. Upregulation of ORL-1 Receptors in Spinal Tissue of Allodynic Rats after Sciatic Nerve Injury. Eur. J. Pharmacol. 2002; 447:59-65. [PubMed: 12106803]

21. Mika J, Schafer MK, Obara I, Weihe E, Przewlocka B. Morphine and Endomorphin-1 Differently Influence Pronociceptin/Orphanin FQ System in Neuropathic Rats. Pharmacol., Biochem. Behav. 2004; 78:171-178. [PubMed: 15159147]

22. Popiolek-Barczyk K, Rojewska E, Jurga AM, Makuch W, Zador F, Borsodi A, Piotrowska A, Przewlocka B, Mika J. Minocycline Enhances the Effectiveness of Nociceptin/Orphanin FQ during Neuropathic Pain. Biomed. Res. Int. 2014; 2014:762930. [PubMed: 25276817]

23. Yamamoto T, Nozaki-Taguchi N, Kimura S. Effects of Intrathecally Administered Nociceptin, an Opioid Receptor-like1 (ORL1) Receptor Agonist, on the Thermal Hyperalgesia Induced by Unilateral Constriction Injury to the Sciatic Nerve in the Rat. Neurosci. Lett. 1997; 224:107-110. [PubMed: 9086468]

24. Mustazza C, Bastanzio G. Development of Nociceptin Receptor (NOP) Agonists and Antagonists. Med. Res. Rev. 2011; 31:605-648. [PubMed: 20099319]

25. Mika J, Obara I, Przewlocka B. The Role of Nociceptin and Dynorphin in Chronic Pain: Implications of Neuro-glial Interaction. Neuropeptides. 2011; 45:247-261. [PubMed: 21477860]

26. Corradini L, Briscini L, Ongini E, Bertorelli R. The Putative $\mathrm{OP}_{4}$ Antagonist, $\left[\right.$ Nphe $^{1}$ ]Nociceptin(1-13) $\mathrm{NH}_{2}$, Prevents the Effects of Nociceptin in Neuropathic Rats. Brain Res. 2001; 905:127-133. [PubMed: 11423087]

27. Khroyan TV, Polgar WE, Jiang F, Zaveri NT, Toll L. Nociceptin/Orphanin FQ Receptor Activation Attenuates Antinociception Induced by Mixed Nociceptin/Orphanin FQ/mu-Opioid Receptor Agonists. J. Pharmacol. Exp. Ther. 2009; 331:946-953. [PubMed: 19713488]

28. Khroyan TV, Polgar WE, Orduna J, Montenegro J, Jiang F, Zaveri NT, Toll L. Differential Effects of Nociceptin/Orphanin FQ (NOP) Receptor Agonists in Acute Versus Chronic Pain: Studies with Bifunctional NOP/ $\mu$ Receptor Agonists in the Sciatic Nerve Ligation Chronic Pain Model in Mice. J. Pharmacol. Exp. Ther. 2011; 339:687-693. [PubMed: 21859931]

29. Scoto GM, Arico G, Ronsisvalle S, Parenti C. Blockade of the Nociceptin/Orphanin FQ/NOP Receptor System in the Rat Ventrolateral Periaqueductal Gray Potentiates DAMGO Analgesia. Peptides. 2007; 28:1441-1446. [PubMed: 17628212]

30. Ko MC, Wei H, Woods JH, Kennedy RT. Effects of Intrathecally Administered Nociceptin/ Orphanin FQ in Monkeys: Behavioral and Mass Spectrometric Studies. J. Pharmacol. Exp. Ther. 2006; 318:1257-1264. [PubMed: 16766718]

31. Micheli L, Di Cesare Mannelli L, Guerrini R, Trapella C, Zanardelli M, Ciccocioppo R, Rizzi A, Ghelardini C, Calo G. Acute and Subchronic Antinociceptive Effects of Nociceptin/Orphanin FQ Receptor Agonists Infused by Intrathecal Route in Rats. Eur. J. Pharmacol. 2015; 754:73-81. [PubMed: 25704616]

32. Obara I, Parkitna JR, Korostynski M, Makuch W, Kaminska D, Przewlocka B, Przewlocki R. Local Peripheral Opioid Effects and Expression of Opioid Genes in the Spinal Cord and Dorsal Root Ganglia in Neuropathic and Inflammatory Pain. Pain. 2009; 141:283-291. [PubMed: 19147290]

33. Khroyan TV, Polgar WE, Orduna J, Zaveri NT, Judd AK, Tuttle DJ, Sanchez A, Toll L. Antinociceptive and Anti-allodynic Effects of a High Affinity NOP Hexapeptide [Ac-RY(3-Cl)YRWR$\mathrm{NH}_{2}$ ] (Syn 1020) in Rodents. Eur. J. Pharmacol. 2007; 560:29-35. [PubMed: 17303110]

34. Mamiya T, Noda Y, Ren X, Nagai T, Takeshima H, Ukai M, Nabeshima T. Morphine Tolerance and Dependence in the Nociceptin Receptor Knockout Mice. J. Neural Transm. 2001; 108:1349-1361. [PubMed: 11810400]

35. Lin AP, Ko MC. The Therapeutic Potential of Nociceptin/Orphanin FQ Receptor Agonists as Analgesics without Abuse Liability. ACS Chem. Neurosci. 2013; 4:214-224. [PubMed: 23421672] 
36. Hu E, Calo G, Guerrini R, Ko MC. Long-lasting Antinociceptive Spinal Effects in Primates of the Novel Nociceptin/Orphanin FQ Receptor Agonist UFP-112. Pain. 2010; 148:107-113. [PubMed: 19945794]

37. Morphy R, Rankovic Z. Designed Multiple Ligands. An Emerging Drug Discovery Paradigm. J. Med. Chem. 2005; 48:6523-6543. [PubMed: 16220969]

38. Johnson RE, Fudala PJ, Payne R. Buprenorphine: Considerations for Pain Management. J. Pain Symptom Manage. 2005; 29:297-326. [PubMed: 15781180]

39. Khroyan TV, Polgar WE, Cami-Kobeci G, Husbands SM, Zaveri NT, Toll L. The First Universal Opioid Ligand, $(2 S)-2-[(5 R, 6 R, 7 R, 14 S)$ - $N$-cyclopropylmethyl-4,5-epoxy-6,14-ethano-3hydroxy-6-meth oxymorphinan-7-yl]-3,3-dimethylpentan-2-ol (BU08028): Characterization of the in vitro Profile and in vivo Behavioral Effects in Mouse Models of Acute Pain and Cocaineinduced Reward. J. Pharmacol. Exp. Ther. 2011; 336:952-961. [PubMed: 21177476]

40. Zaveri NT, Jiang F, Olsen CM, Deschamps JR, Parrish D, Polgar W, Toll L. A Novel Series of Piperidin-4-yl-1,3-Dihydroindol-2-ones as Agonist and Antagonist Ligands at the Nociceptin Receptor. J. Med. Chem. 2004; 47:2973-2976. [PubMed: 15163178]

41. Zaveri NT, Jiang F, Olsen C, Polgar WE, Toll L. Designing Bifunctional NOP Receptor-mu Opioid Receptor Ligands from NOP Receptor-selective Scaffolds. Part I. Bioorg. Med. Chem. Lett. 2013; 23:3308-3313. [PubMed: 23623415]

42. Blair Journigan V, Polgar WE, Khroyan TV, Zaveri NT. Designing Bifunctional NOP Receptor-mu Opioid Receptor Ligands from NOP-Receptor Selective Scaffolds. Part II. Bioorg. Med. Chem. 2014; 22:2508-2516. [PubMed: 24657054]

43. Khroyan TV, Zaveri NT, Polgar WE, Orduna J, Olsen C, Jiang F, Toll L. SR 16435 [1-(1(bicyclo[3.3.1]nonan-9-yl)piperidin-4-yl)indolin-2-one], a Novel Mixed Nociceptin/Orphanin FQ/mu-opioid Receptor Partial Agonist: Analgesic and Rewarding Properties in Mice. J. Pharmacol. Exp. Ther. 2007; 320:934-943. [PubMed: 17132815]

44. Schunk S, Linz K, Hinze C, Frormann S, Oberbörsch S, Sundermann B, Zemolka S, Englberger W, Germann T, Christoph T, Kögel B-Y, Schröder W, Harlfinger S, Saunders D, Kless A, Schick H, Sonnenschein H. Discovery of a Potent Analgesic NOP and Opioid Receptor Agonist: Cebranopadol. ACS Med. Chem. Lett. 2014; 5:857-862. [PubMed: 25147603]

45. Khroyan TV, Polgar WE, Orduna J, Jiang F, Olsen C, Toll L, Zaveri NT. Activity of New NOP Receptor Ligands in a Rat Peripheral Mononeuropathy Model: Potentiation of Morphine Antiallodynic Activity by NOP Receptor Antagonists. Eur. J. Pharmacol. 2009; 610:49-54. [PubMed: 19285491]

46. Linz K, Christoph T, Tzschentke TM, Koch T, Schiene K, Gautrois M, Schröder W, Kögel BY, Beier H, Englberger W, Schunk S, De Vry J, Jahnel U, Frosch S. Cebranopadol: A Novel Potent Analgesic Nociceptin/Orphanin FQ Peptide and Opioid Receptor Agonist. J. Pharmacol. Exp. Ther. 2014; 349:535-548. [PubMed: 24713140]

47. Cami-Kobeci G, Polgar WE, Khroyan TV, Toll L, Husbands SM. Structural Determinants of Opioid and NOP Receptor Activity in Derivatives of Buprenorphine. J. Med. Chem. 2011; 54:6531-6537. [PubMed: 21866885]

48. Yamamoto T, Shono K, Tanabe S. Buprenorphine Activates $\mu$ and Opioid Receptor Like-1 Receptors Simultaneously, but the Analgesic Effect Is Mainly Mediated by $\mu$ Receptor Activation in the Rat Formalin Test. J. Pharmacol. Exp. Ther. 2006; 318:206-213. [PubMed: 16565164]

49. Cremeans CM, Gruley E, Kyle DJ, Ko M-C. Roles of $\mu$-Opioid Receptors and Nociceptin/ Orphanin FQ Peptide Receptors in Buprenorphine-Induced Physiological Responses in Primates. J. Pharmacol. Exp. Ther. 2012; 343:72-81. [PubMed: 22743574]

50. Kawano S, Ambo A, Sasaki Y. Synthesis and Receptor Binding Properties of Chimeric Peptides Containing a $\mu$-Opioid Receptor Ligand and Nociceptin/Orphanin FQ Receptor Ligand AcRYYRIK-amide. Bioorg. Med. Chem. Lett. 2006; 16:4839-4841. [PubMed: 16814543]

51. Kawano S, Ito R, Nishiyama M, Kubo M, Matsushima T, Minamisawa M, Ambo A, Sasaki Y. Receptor Binding Properties and Antinociceptive Effects of Chimeric Peptides Consisting of a $\mu$ Opioid Receptor Agonist and an ORL1 Receptor Antagonist. Biol. Pharm. Bull. 2007; 30:12601264. [PubMed: 17603164] 
52. Becker JAJ, Wallace A, Garzon A, Ingallinella P, Bianchi E, Cortese R, Simonin F, Kieffer BL, Pessi A. Ligands for $\kappa$-Opioid and ORL1 Receptors Identified from a Conformationally Constrained Peptide Combinatorial Library. J. Biol. Chem. 1999; 274:27513-27522. [PubMed: 10488086]

53. Bigoni R, Rizzi A, Rizzi D, Becker JA, Kieffer BL, Simonin F, Regoli D, Calo G. In vitro Pharmacological Profile of Peptide III-BTD: A Novel Ligand for Nociceptin/Orphanin FQ and Opioid Receptors. Life Sci. 2000; 68:233-239. [PubMed: 11191640]

54. Judd AK, Tuttle DJ, Jones RW, Sanchez A, Polgar W, Berzetei-Gurske I, Toll L. Structure-activity Studies on High Affinity NOP-active Hexapeptides. J. Pept. Res. 2004; 64:87-94. [PubMed: 15317498]

55. Berger H, Albrecht E, Wallukat G, Bienert M. Antagonism by Acetyl-RYYRIK-NH2 of G Protein Activation in Rat Brain Preparations and of Chronotropic Effect on Rat Cardiomyocytes Evoked by Nociceptin/Orphanin FQ. Br. J. Pharmacol. 1999; 126:555-558. [PubMed: 10188961]

56. Guillemyn K, Kleczkowska P, Lesniak A, Dyniewicz J, Van der Poorten O, Van den Eynde I, Keresztes A, Varga E, Lai J, Porreca F, Chung NN, Lemieux C, Mika J, Rojewska E, Makuch W, Van Duppen J, Przewlocka B, Van den Broeck J, Lipkowski AW, Schiller PW, Tourwé D, Ballet S. Synthesis and Biological Evaluation of Compact, Conformationally Constrained Bifunctional Opioid Agonist - Neurokinin-1 Antagonist Peptidomimetics. Eur. J. Med. Chem. 2015; 92:64-77. [PubMed: 25544687]

57. Dooley CT, Spaeth CG, Berzetei-Gurske IP, Craymer K, Adapa ID, Brandt SR, Houghten RA, Toll L. Binding and In Vitro Activities of Peptides with High Affinity for the Nociceptin/Orphanin FQ Receptor, ORL1. J. Pharmacol. Exp. Ther. 1997; 283:735-741. [PubMed: 9353393]

58. Tourwe D, Verschueren K, Van Binst G, Davis P, Porreca F, Hruby V. Dermorphin Sequence with High Delta-affinity by Fixing the Phe Side-chain to Trans at Alpha-1. Bioorg. Med. Chem. Lett. 1992; 2:1305-1308.

59. Tourwe D, Verschueren K, Frycia A, Davis P, Porreca F, Hruby V, Toth G, Jaspers H, Verheyden P, Van Binst G. Conformational Restriction of Tyr and Phe Side-chain in Opioid Peptides: Information about Preferred and Bioactive Side-chain Topology. Biopolymers. 1996; 38:1-12. [PubMed: 8679939]

60. Ballet S, Frycia A, Piron J, Chung N, Schiller P, Kosson P, Lipkowski A, Tourwe D. Synthesis and Biological Evaluation of Constrained Analogues of the Opioid Peptide H-Tyr-D-Ala-Phe-Gly- $\mathrm{NH}_{2}$ Using 4-Amino-2-Benzazepin-3-one Scaffold. J. Pept. Res. 2005; 66:222-230. [PubMed: 16218989]

61. Vandormael B, Fourla D-D, Gramowski-Voß A, Kosson P, Weiss D, Schroder O-U, Lipkowski A, Georgoussi Z, Tourwe D. Superpotent [Dmt ${ }^{1}$ ]Dermorphin Tetrapeptides Containing the 4Aminotetrahydro-2-Benzazepin-3-one Scaffold with Mixed $\mu / \delta$ Opioid Receptor Agonistic Properties. J. Med. Chem. 2011; 54:7848-7859. [PubMed: 21978284]

62. Ballet S, Mayorov AV, Cai M, Tymecka D, Chandler KB, Palmer ES, Rompaey KV, Misicka A, Tourwe D, Hruby VJ. Novel Selective Human Melanocortin-3 Receptor Ligands: Use of the 4Amino-1,2,4,5-Tetrahydro-2-Benzazepin-3-one (Aba) Scaffold. Bioorg. Med. Chem. Lett. 2007; 17:2492-2498. [PubMed: 17314042]

63. Ballet S, De Wachter R, Van Rompaey K, Tömböly C, Feytens D, Töth G, Quartara L, Cucchi P, Meini S, Tourwé D. Bradykinin Analogs Containing the 4-Amino-2-Benzazepin-3-one Scaffold at the C-terminus. J. Pept. Sci. 2007; 13:164-170. [PubMed: 17266049]

64. Robl JA, Sun CQ. Processes and Intermediates for Preparing Benzo-Fused Azepinone and Piperidinone Compounds Useful in the Inhibition of ACE and NEP. U.S. Patent. 2001; 6(6235): 922.

65. Maldonado R, Severini C, Matthes HWD, Kieffer BL, Melchiorri P, Negri L. Activity of mu- and delta-Opioid Agonists in Vas Deferens from Mice Deficient in MOR Gene. Br. J. Pharmacol. 2001; 132:1485-1492. [PubMed: 11264242]

66. Spagnolo B, Calo G, Polgar WE, Jiang F, Olsen CM, Berzetei-Gurske I, Khroyan TV, Husbands SM, Lewis JW, Toll L, Zaveri NT. Activities of Mixed NOP and $\mu$-opioid Receptor Ligands. Br. J. Pharmacol. 2008; 153:609-619. [PubMed: 18059322] 
67. Di L, Kerns EH, Fan K, McConnell OJ, Carter GT. High Throughput Artificial Membrane Permeability Assay for Blood-Brain Barrier. Eur. J. Med. Chem. 2003; 38:223-232. [PubMed: 12667689]

68. Cecchelli R, Aday S, Sevin E, Almeida C, Culot M, Dehouck L, Coisne C, Engelhardt B, Dehouck M-P, Ferreira L. A Stable and Reproducible Human Blood-Brain Barrier Model Derived from Hematopoietic Stem Cells. PLoS One. 2014; 9:e99733. [PubMed: 24936790]

69. Aigner A, Wolf S, Gassen HG. Transport and Detoxication: Principles, Approaches, and Perspectives for Research on the Blood -Brain Barrier. Angew. Chem., Int. Ed. Engl. 1997; 36:2441.

70. Hitchcock SA, Pennington LD. Structure-Brain Exposure Relationships. J. Med. Chem. 2006; 49:7559-7583. [PubMed: 17181137]

71. Mika J, Osikowicz M, Rojewska E, Korostynski M, Wawrzczak-Bargiela A, Przewlocki R, Przewlocka B. Differential Activation of Spinal Microglial and Astroglial Cells in a Mouse Model of Peripheral Neuropathic Pain. Eur. J. Pharmacol. 2009; 623:65-72. [PubMed: 19766105]

72. Zychowska M, Rojewska E, Kreiner G, Nalepa I, Przewlocka B, Mika J. Mnocycline Influences the Anti-inflammatory Interleukins and Enhances the Effectiveness of Morphine Under Mice Diabetic Neuropathy. J. Neuroimmunol. 2013; 262:35-45. [PubMed: 23870534]

73. Guillemyn K, Costante R, Starnowska J, Szabolcs D, Chung NN, Lemieux C, Przewlocka B, Schiller PW, Vanden Broeck J, Tömböly C, Tourwé D, Mollica A, de Graaf C, Ballet S. Unpublished work.

74. Costigan M, Scholz J, Woolf CJ. Neuropathic Pain: A Maladaptive Response of the Nervous System to Damage. Annu. Rev. Neurosci. 2009; 32:1-32. [PubMed: 19400724]

75. Mogil JS, Wilson SG, Bon K, Eun Lee S, Chung K, Raber P, Pieper JO, Hain HS, Belknap JK, Hubert L, Elmer GI, Mo Chung J, Devor M. Heritability of Nociception II. 'Types' of Nociception Revealed by Genetic Correlation Analysis. Pain. 1999; 80:83-93. [PubMed: 10204720]

76. Shir Y, Seltzer Z. A-fibersMediate Mechanical Hyperesthesia and Allodynia and C-fibers Mediate Thermal Hyperalgesia in a New Model of Causalgiform Pain Disorders in Rats. Neurosci. Lett. 1990; 115:62-67. [PubMed: 2216058]

77. Chevillard L, Megarbane B, Risede P, Baud FJ. Characteristics and Comparative Severity of Respiratory Response to Toxic Doses of Fentanyl, Methadone, Morphine, and Buprenorphine in Rats. Toxicol. Lett. 2009; 191:327-340. [PubMed: 19819313]

78. Simonin F, Schmitt M, Laulin JP, Laboureyras E, Jhamandas JH, MacTavish D, Matifas A, Mollereau C, Laurent P, Parmentier M, Kieffer BL, Bourguignon JJ, Simonnet G. RF9, a Potent and Selective Neuropeptide FF Receptor Antagonist, Prevents Opioid-induced Tolerance Associated with Hyperalgesia. Proc. Natl. Acad. Sci. U. S. A. 2006; 103:466-471. [PubMed: 16407169]

79. Arunlakshana O, Schild HO. Some Quantitative Uses of Drug Antagonists. Br. J. Pharmacol. Chemother. 1959; 14:48-58. [PubMed: 13651579]

80. DiMaio J, Nguyen T, Lemieux C, Schiller P. Synthesis amd Pharmacological Characterization in vitro of Cyclic Enkephalin Analogues: Effect of the Conformational Constraints on Opioid Receptor Selectivity. J. Med. Chem. 1982; 25:1432-1438. [PubMed: 6296388]

81. Waterfield AA, Leslie FM, Lord JAH, Ling N, Kosterlitz HW. Opioid Activities of Fragments of $\beta$ Endorphin and of its Lucine65-analogue. Comparison of the Binding Properties of Methionineand Leucine-enkephalin. Eur. J. Pharmacol. 1979; 58:11-18. [PubMed: 499333]

82. Mohamadi F, Richards NGJ, Guida WC, Liskamp R, Lipton M, Caufield C, Chang G, Hendrickson T, Still WC. Macromodel - an Integrated Software System for Modeling Organic and Bioorganic Molecules Using Molecular Mechanics. J. Comput. Chem. 1990; 11:440-467.

83. Arranz-Gibert P, Guixer B, Malakoutikhah M, Muttenthaler M, Guzmán F, Teixidó M, Giralt E. Lipid Bilayer Crossing - The Gate of Symmetry. Water-Soluble Phenylproline-Based Blood-Brain Barrier Shuttles. J. Am. Chem. Soc. 2015; 137:7357-7364. [PubMed: 25992679]

84. Bennett GJ, Xie YK. A Peripheral Mononeuropathy in Rat that Produces Disorders of Pain Sensation Like Those Seen in Man. Pain. 1988; 33:87-107. [PubMed: 2837713] 
85. Mika J, Osikowicz M, Makuch W, Przewlocka B. Minocycline and Pentoxifylline Attenuate Allodynia and Hyperalgesia and Potentiate the Effects of Morphine in Rat and Mouse Models of Neuropathic Pain. Eur. J. Pharmacol. 2007; 560:142-149. [PubMed: 17307159]

86. Hylden JL, Wilcox GL. Intrathecal Morphine in Mice: a New Technique. Eur. J. Pharmacol. 1980; 67:313-316. [PubMed: 6893963]

87. Fairbanks CA. Spinal Delivery of Analgesics in Experimental Models of Pain and Analgesia. Adv. Drug Delivery Rev. 2003; 55:1007-1041.

88. Bartlett D, Tenney SM. Control of Breathing in Experimental Anemia. Respir. Physiol. 1970; 10:384-395. [PubMed: 5476156] 


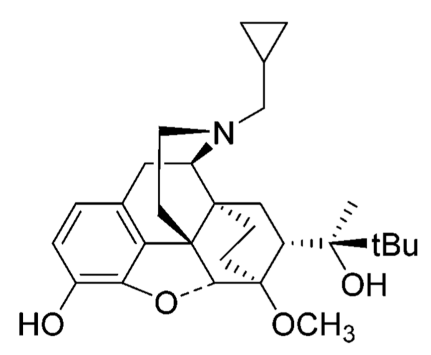

buprenorphine 1

MOP, KOP partial agonist NOP partial agonist

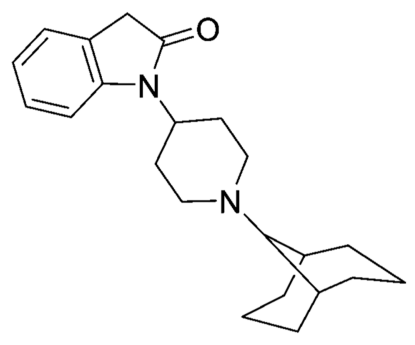

SR16435 2

MOP partial agonist NOP partial agonist

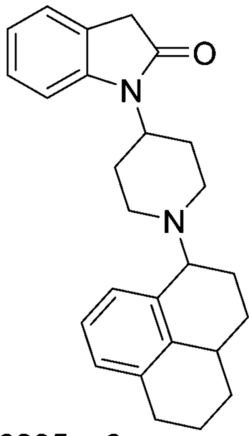

SR16835 3

MOP low agonist potency NOP full agonist
F

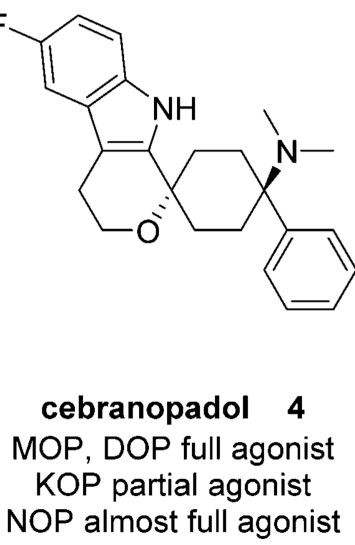

SPYGFaY-GG Ac-RYYRIK-GGG-K-NH

dimeric peptide 5

MOP agonist

NOP: not reported

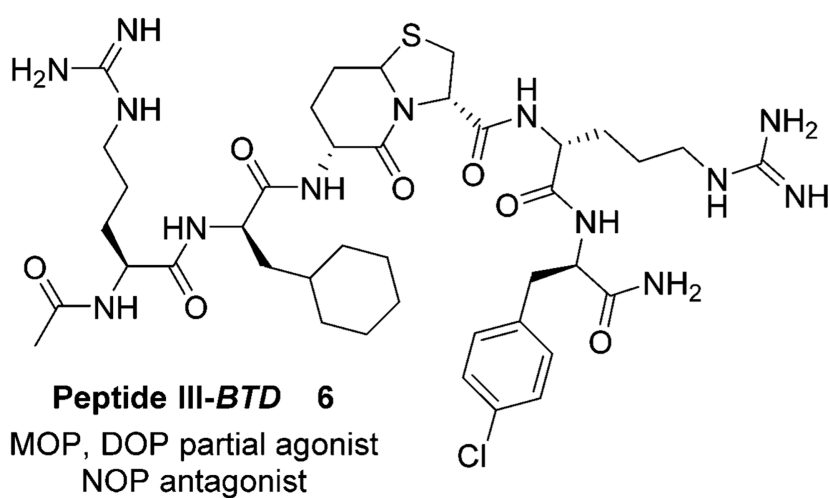

Figure 1.

Examples of reported opioid-NOP bifunctional ligands: $\mathbf{1}^{38,47-49} \mathbf{2}^{28,42} \mathbf{3}^{43} \mathbf{4}^{44,46}$ a chimeric peptide $\mathbf{5}^{50,51}$ and $\mathbf{6}^{52,53}$ 

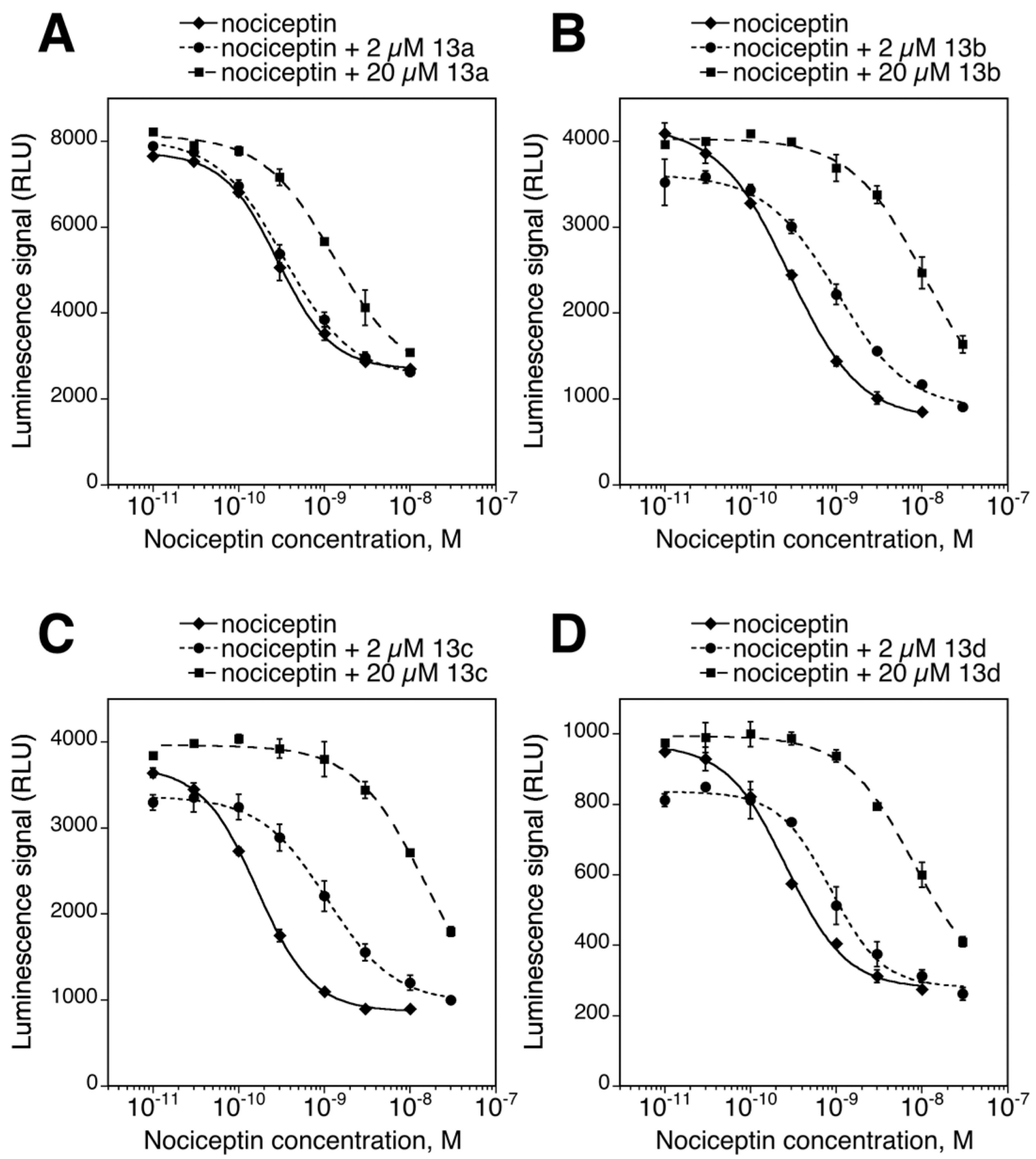

Figure 2.

Inhibition of nociceptin effect on forskolin-stimulated cAMP accumulation by hybrids 13a13d in HEK293 stably expressing human NOP receptor. Dose-response curves of nociceptin were performed in absence or presence of 2 and $20 \mu \mathrm{M}$ of each compound. This figure shows a representative experiment. Evaluation were performed at least two times in duplicate. 


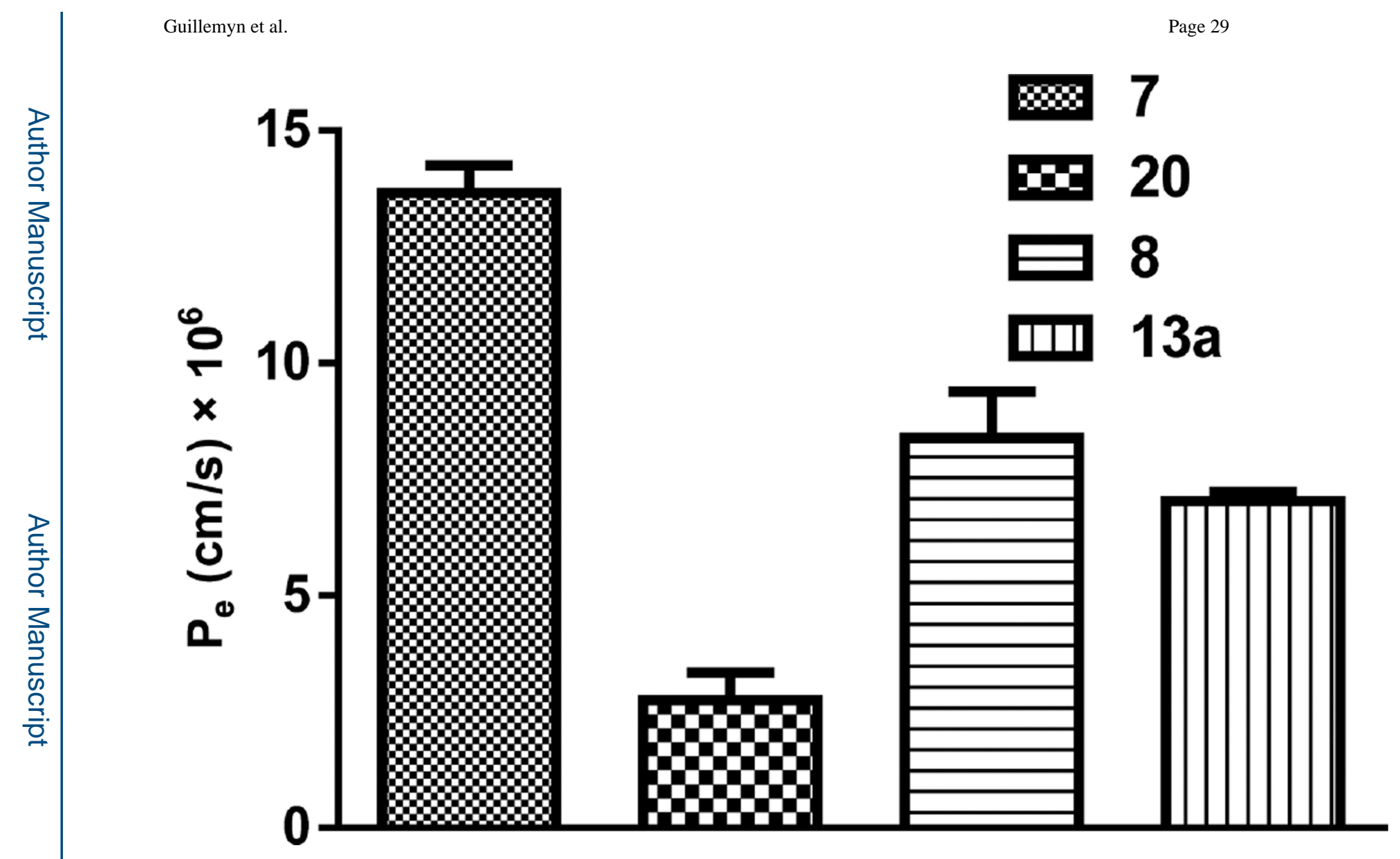

Figure 3.

Peptide transport in an in vitro cell-based model of the BBB. 


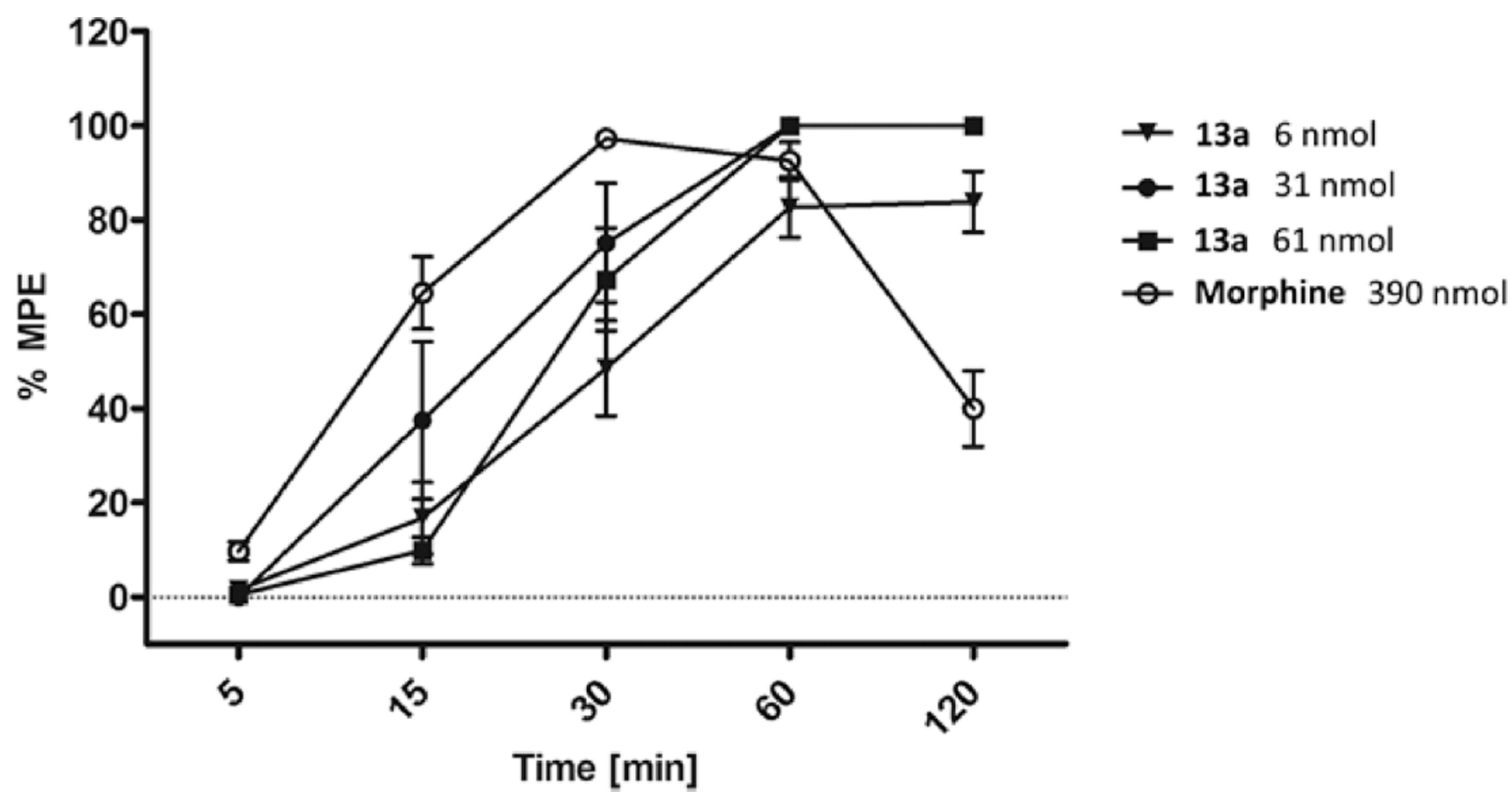

Figure 4.

Time and dose dependent analgesic effect of 13a after iv administration compared to morphine. Ordinal values represent tail-flick latency measurements which were normalized as $\% \mathrm{MPE}($ mean $\pm \mathrm{SEM})$. 

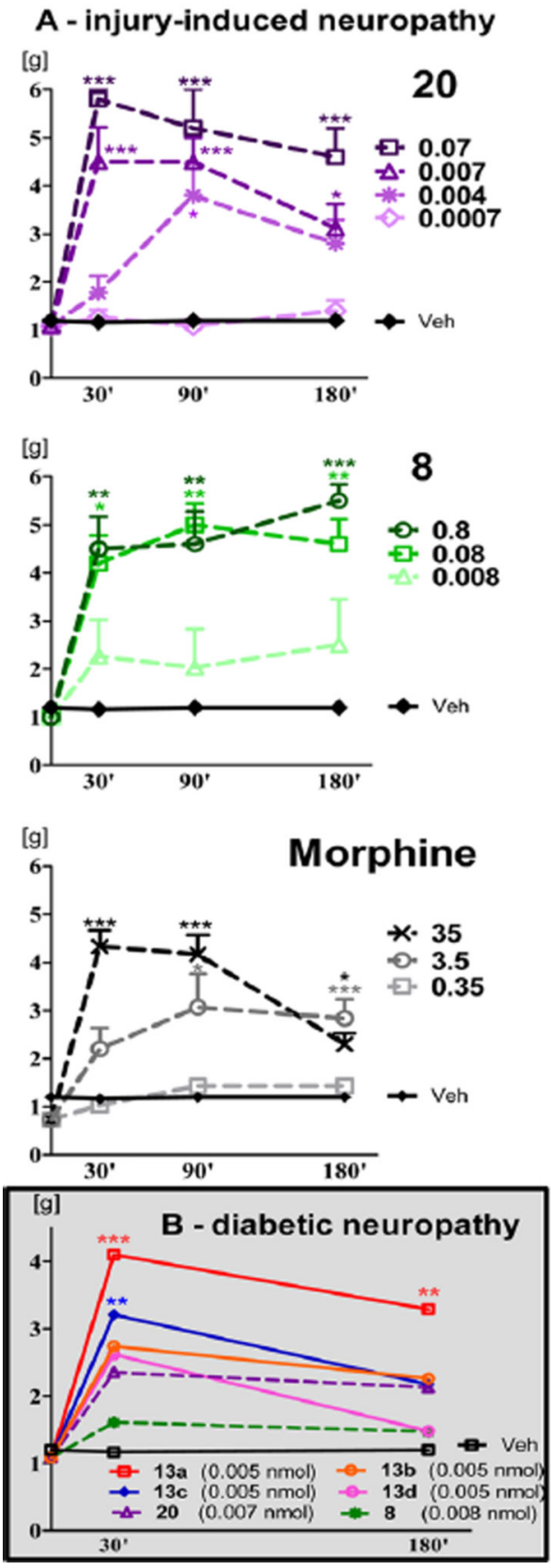

von Frey test
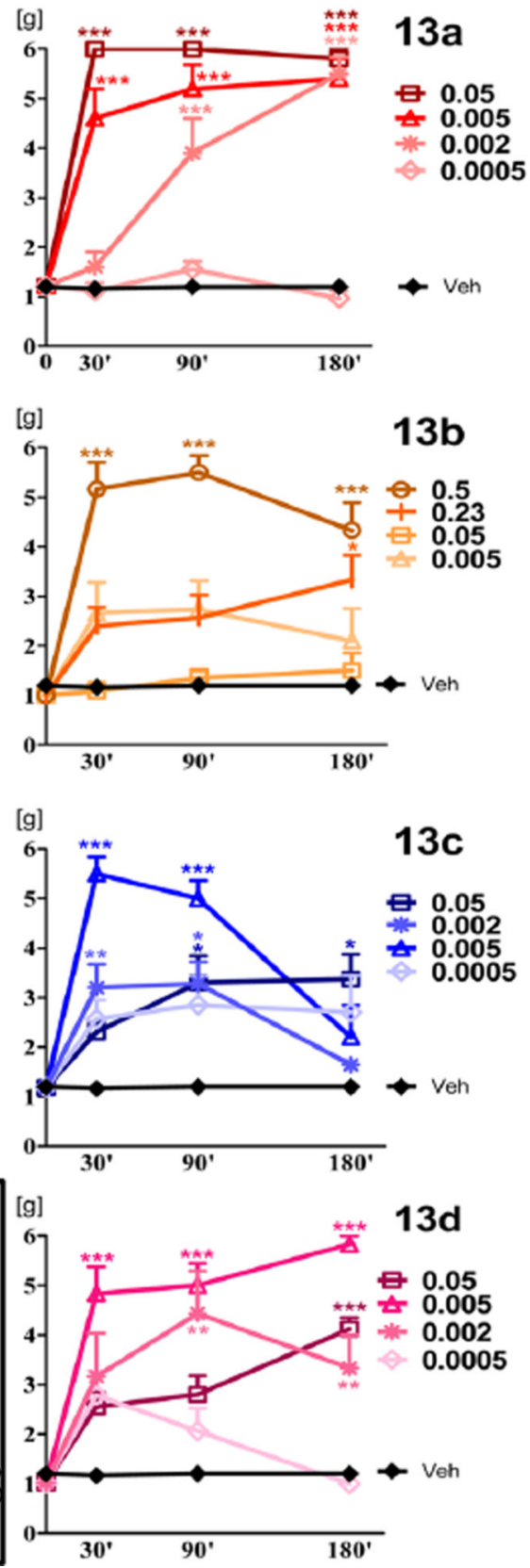

Figure 5.

Effect of intrathecal (it) administration of hybrids 13a-13d and nociceptin parents 8 and $\mathbf{2 0}$ and morphine (all doses in nmol, 6-8 animals per group) on allodynia in CCI (A) and STZ (B) mice. As naive mice do not react to non-noxious stimuli, their reaction threshold may be established close to $(5.9 \pm 0.1 \mathrm{~g})$ cutoff level $(6 \mathrm{~g})$. In comparison, the reaction threshold in CCI mice is $1.03 \pm 0.07 \mathrm{~g}$. 
A - injury-induced neuropathy
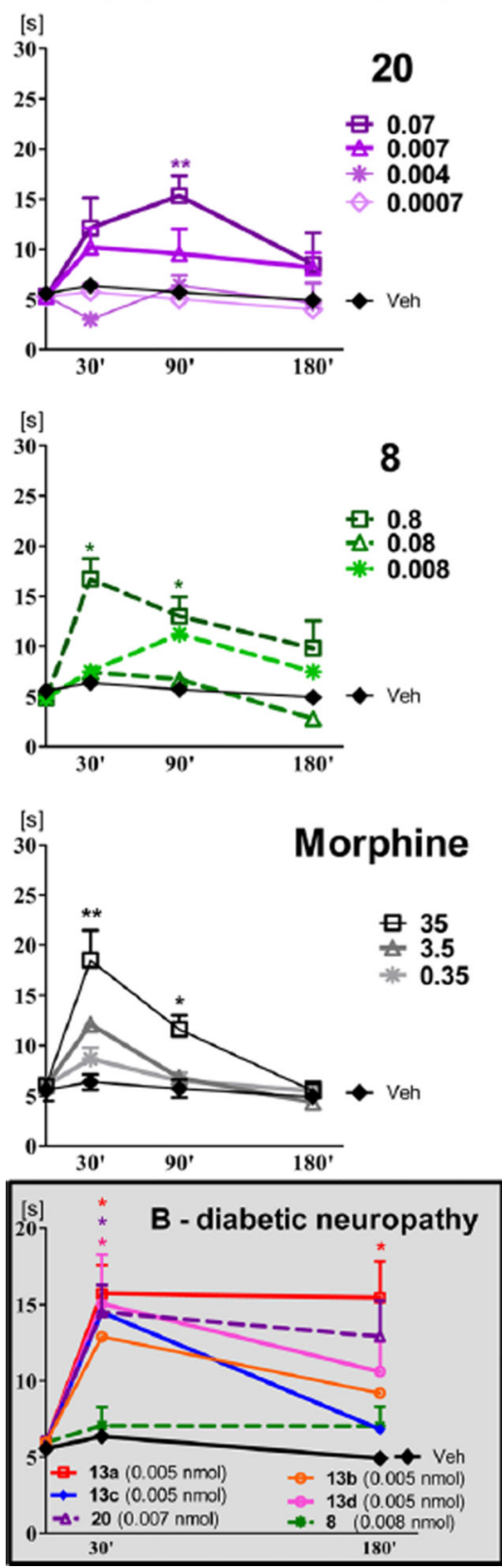

cold plate test
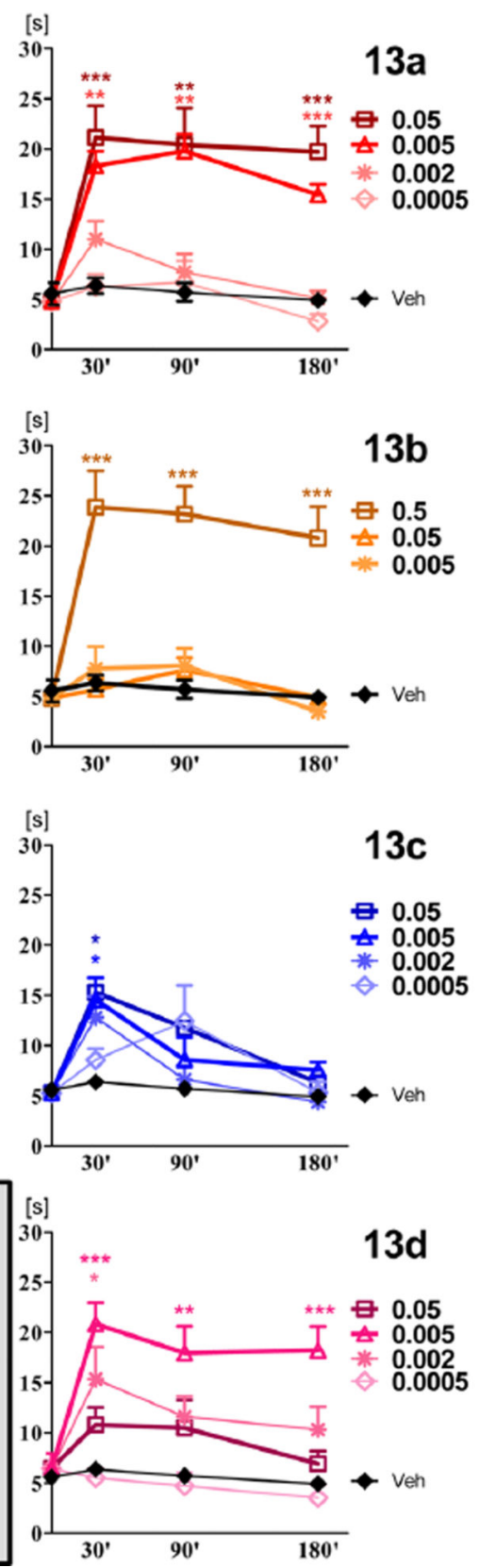

Figure 6.

Effect of intrathecal (it) administration of hybrids 13a-13d and nociceptin parents 8 and $\mathbf{2 0}$ and morphine (all doses in nmol, 6-8 animals per group) on hyperalgesia in CCI (A) and STZ (B) mice. The naive mice very poorly respond to noxious thermal stimuli in cold plate test (26.8 $\pm 0.45 \mathrm{~s})$, and the value is close to cutoff level ( $30 \mathrm{~s})$. In comparison, the reaction threshold in CCI mice is $5.4 \pm 0.3 \mathrm{~s}$. 

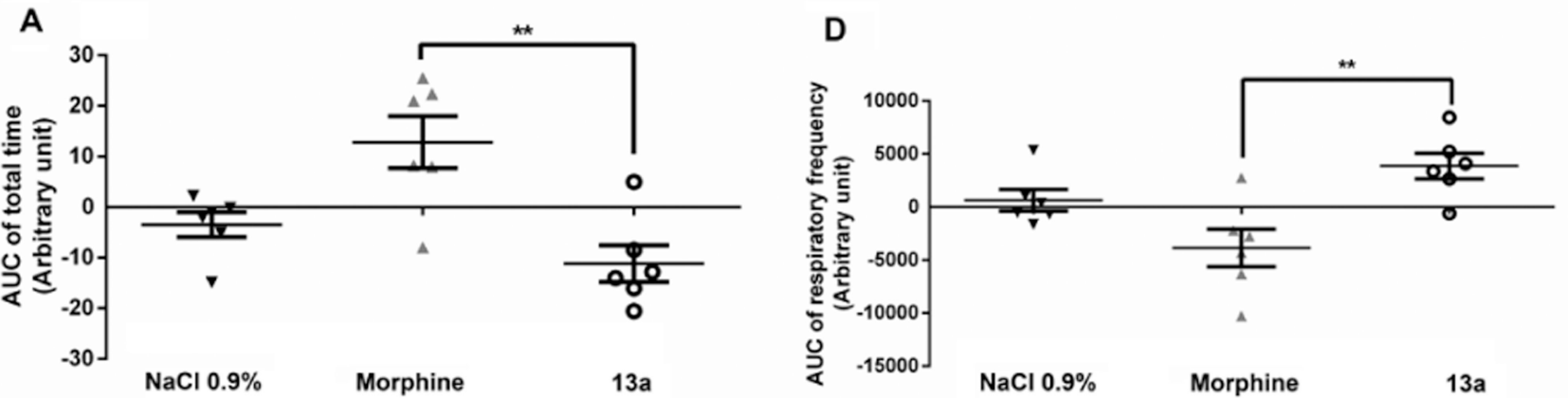

B
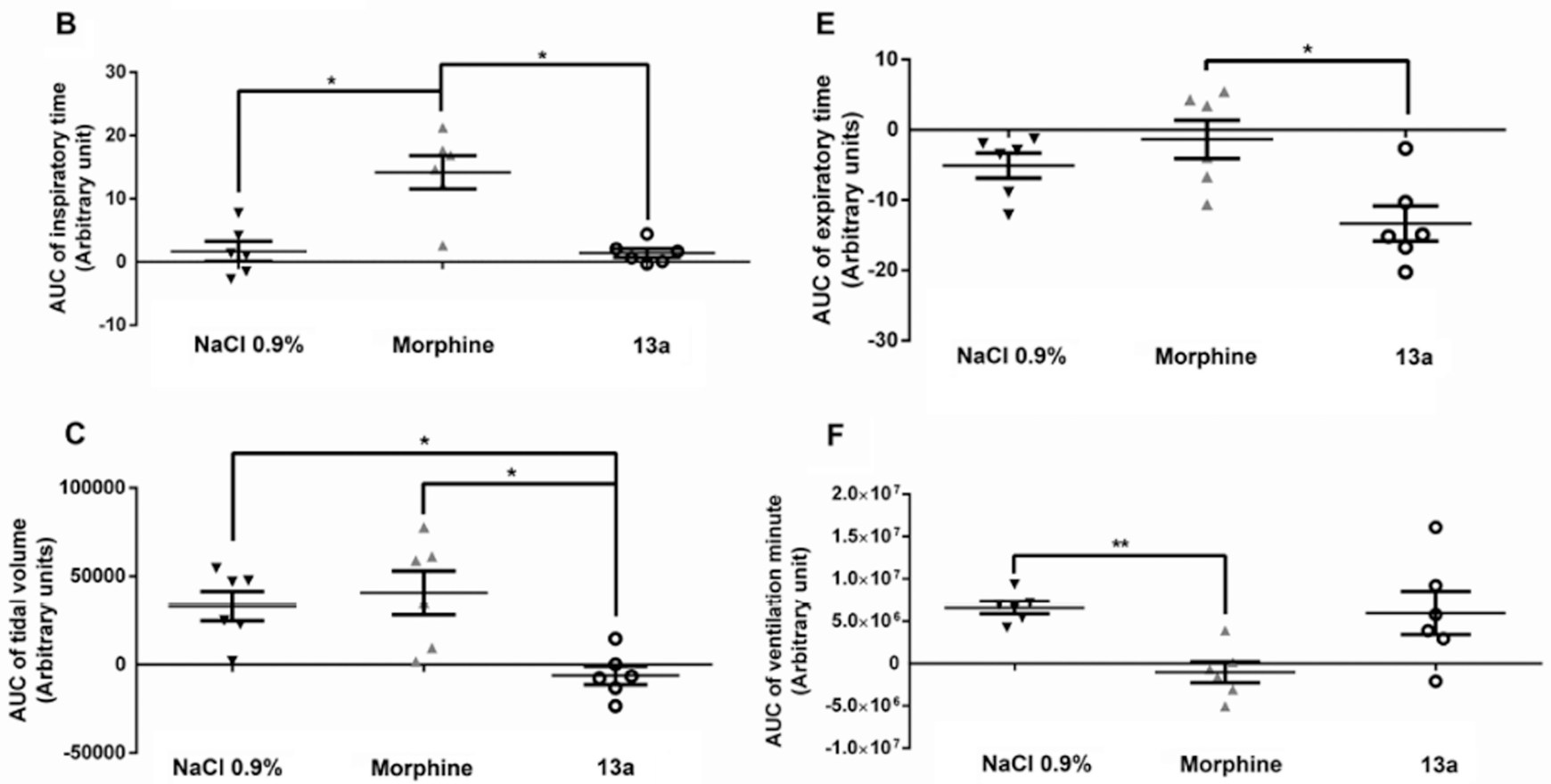

Figure 7.

Effects in Sprague-Dawley rats of intravenous 13a $(0.5 \mathrm{mg} / \mathrm{kg}$, open circles), morphine ( 5 $\mathrm{mg} / \mathrm{kg}$, gray triangles), and $0.9 \% \mathrm{NaCl}$ (black triangles) on plethysmography parameters ( $N$ $=6 /$ group). Areas under the effect-time curve (AUC) were determined. Results are expressed as mean \pm SEM. Comparisons were performed using Kruskal-Wallis tests. ${ }^{*} p<0.05$, $* * p<$ 0.01 . 


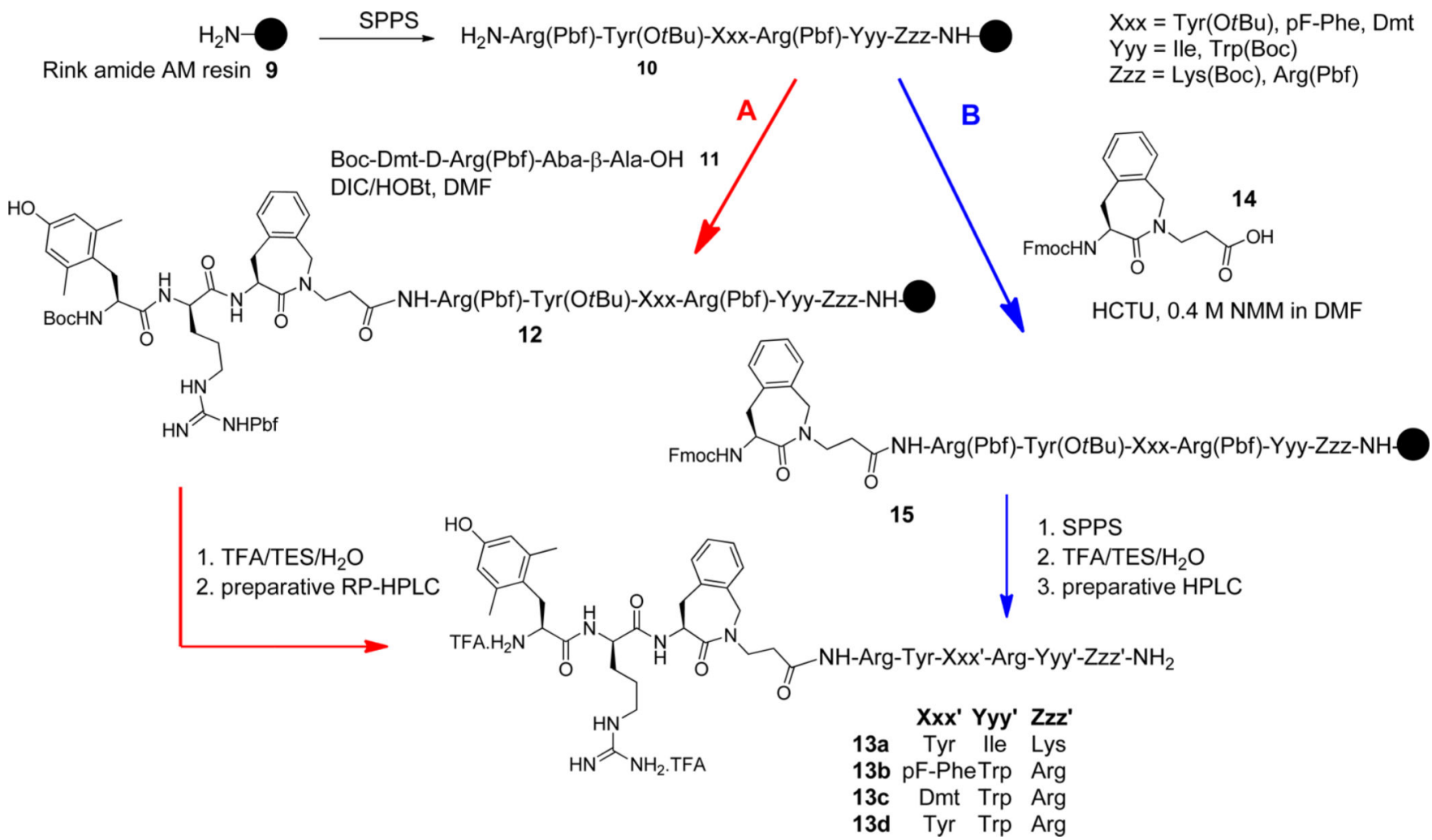

Scheme 1.

Solid Phase Synthesis of the Bifunctional Opioid-Nociceptin Peptides 
Guillemyn et al.<smiles>O=C(O)[C@H](Cc1ccccc1)N1C(=O)c2ccccc2C1=O</smiles><smiles>[Y7][Y](=O)(O)[C@H](Cc1ccccc1)N1C(=O)c2ccccc2C1=O</smiles>

16

17<smiles>CCOC(=O)CCN1Cc2ccccc2C[C@H](N2C(=O)c3ccccc3C2=O)C1=O</smiles><smiles>O=C(O)CCN1Cc2ccccc2CC(NC(F)F)C1=O</smiles>

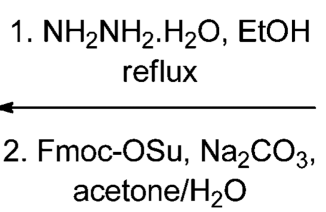

$54 \%$<smiles>O=C(O)CCN1Cc2ccccc2C[C@H](N2C(=O)c3ccccc3C2=O)C1=O</smiles>

19

Scheme 2.

Synthesis of Dipeptidomimetic Fmoc-Aba- $\beta$-Ala-OH (14) 


\section{Table 1}

Compound Numbers, Sequences, and Yields of the Bifunctional Peptides

\begin{tabular}{clc}
\hline compd & sequence & yield (\%) \\
\hline 13a & H-Dmt-D-Arg-Aba- $\beta$-Ala-Arg-Tyr-Tyr-Arg-Ile-Lys- $\mathrm{NH}_{2}$ & $18(\mathrm{~A}) / 25(\mathrm{~B})$ \\
$\mathbf{1 3 b}$ & H-Dmt-D-Arg-Aba- $\beta$-Ala-Arg-Tyr-(pF-Phe)-Arg-Trp-Arg-NH & 17 \\
$\mathbf{1 3 c}$ & H-Dmt-D-Arg-Aba- $\beta$-Ala-Arg-Tyr-Dmt-Arg-Trp-Arg-NH & 23 \\
13d & H-Dmt-D-Arg-Aba- $\beta$-Ala-Arg-Tyr-Tyr-Arg-Trp-Arg-NH & 23 \\
\hline
\end{tabular}




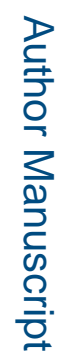

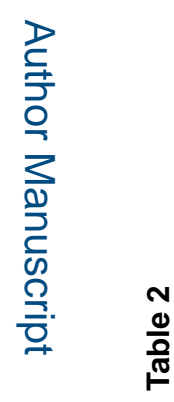

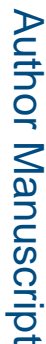

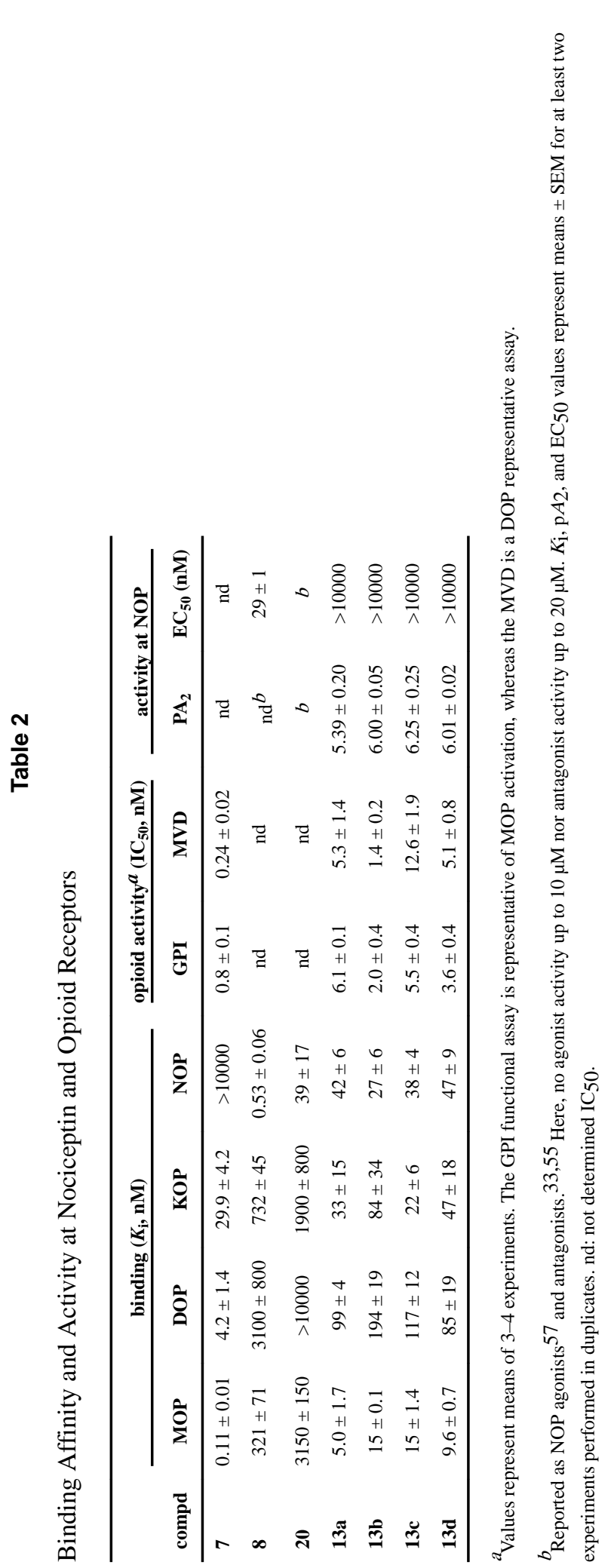


Table 3

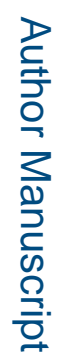

Transport in BBB-PAMPA Assay

\begin{tabular}{lcccc}
\hline no. & $\begin{array}{c}\boldsymbol{P}_{\mathbf{e}}(\mathbf{c m} / \mathbf{s}) \times \\
\mathbf{1 0}^{-\mathbf{6}}\end{array}$ & $\begin{array}{c}\mathbf{S D ~} \boldsymbol{P}_{\mathbf{e}}(\mathbf{c m} / \mathbf{s}) \times \\
\mathbf{1 0}^{-\mathbf{6}}\end{array}$ & $\begin{array}{c}\text { transport } \\
(\mathbf{\%})\end{array}$ & $\begin{array}{c}\text { SD transport } \\
(\mathbf{\%})\end{array}$ \\
\hline $\mathbf{7}$ & 0.9 & 0.6 & 1.8 & 1.3 \\
$\mathbf{2 0}$ & $\mathrm{nd}^{a}$ & $\mathrm{nd}^{a}$ & $\mathrm{nd}^{a}$ & $\mathrm{nd}^{a}$ \\
$\mathbf{8}$ & 0.07 & 0.05 & 0.15 & 0.10 \\
$\mathbf{1 3 a}$ & 0.11 & 0.02 & 0.23 & 0.04 \\
propranolol & 8.59 & 0.8 & 15.2 & 1.4 \\
\hline
\end{tabular}

${ }^{a}$ nd: not detected. 

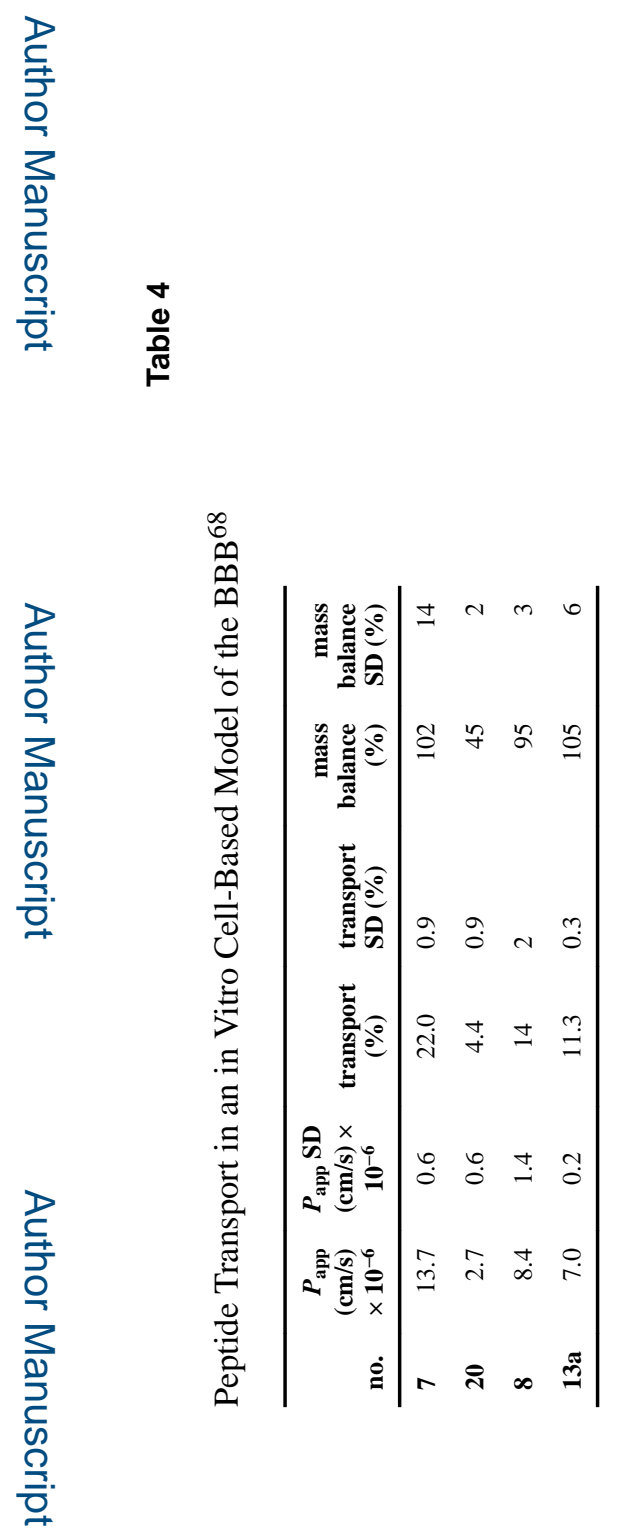

JMed Chem. Author manuscript; available in PMC 2016 April 28. 


\section{Table 5}

Calculated $\mathrm{ED}_{50}$ Values for Effect of Hybrids (13a-13d), Opioid Parent Compound 7, Nociceptin Parent Compounds 8 and 20, and Morphine 30 min after Their Administration in Neuropathic Pain CCI Model in Mice, 7-14 Days after Surgical Procedure ${ }^{a}$

\begin{tabular}{lcc}
\hline & \multicolumn{2}{c}{ response at 30 min $-\mathbf{E D}_{\mathbf{5 0}}$} \\
\cline { 2 - 3 } compd & von Frey & cold plate \\
\cline { 2 - 3 } dose in nmol it) with confidence interval 95\% \\
$\mathbf{7}$ & $0.85(0.22-11.30)$ & $1.60(0.51-5.07)$ \\
$\mathbf{8}$ & $0.008(0.0002-0.4)$ & $0.69(0.13-3.5)$ \\
$\mathbf{2 0}$ & $0.004(0.001-0.01)$ & $0.06(0.02-0.15)$ \\
$\mathbf{1 3 a}$ & $0.003(0.001-0.005)$ & $0.004(0.001-0.01)$ \\
$\mathbf{1 3 b}$ & $0.18(0.06-0.5)$ & $0.14(0.1-0.21)$ \\
$\mathbf{1 3 c}$ & $0.0009(0.0001-0.03)$ & $0.005(0.001-0.02)$ \\
13d & $0.0009(0.0001-0.05)$ & $0.002(0.001-0.003)$ \\
morphine & $7(0.63-76.75)$ & $7.46(1.57-35)$ \\
\hline
\end{tabular}

${ }^{a}$ Allodynia was measured by the von Frey test, and hyperalgesia was measured by the cold plate test. 